\title{
Post-Brexit back-shoring strategies: What UK manufacturing companies could learn from the past?
}

\section{Hamid Moradlou*}

Centre for Logistics, Procurement and Supply Chain Management, School of Management, Cranfield, MK43 OAL,UK

Corresponding Author (hamid.moradlou@cranfield.ac.uk)

\section{Luciano Fratocchi}

Department of Industrial and Information Engineering \& Economics, University of L'Aquila, L'Aquila, Italy (luciano.fratocchi@univaq.it)

\section{Heather Skipworth}

Centre for Logistics, Procurement and Supply Chain Management, School of Management, Cranfield, MK43 OAL,UK (heather.skipworth@cranfield.ac.uk)

\section{Abhijeet Ghadge}

Centre for Logistics, Procurement and Supply Chain Management, School of Management, Cranfield, MK43 0AL, UK (ㅎhijeet.Ghadge@cranfield.ac.uk) 


\begin{abstract}
The manufacturing sector in the UK is currently undergoing a significant supply chain transformation and managers are re-evaluating supply chain location decisions to minimise the disruptions caused by Brexit. This entails manufacturing offshoring and back-shoring once again being considered as strategic decisions and companies ought to make informed choices with respect to where they source or manufacture their products. This paper aims to contribute to an improved understanding of the back-shoring phenomenon in the UK. Eight case studies of back-shoring have been analysed and compared using a theoretically informed framework. The results shows that back-shoring can stem from both misjudgements of previous offshoring decisions as well as changes in the demand pattern at the home country. Unlike offshoring decisions being mainly cost-oriented, strategic shift aimed at increasing the value perceived by the customer has a pivotal role in the back-shoring decision. Furthermore, skill shortage is the main barrier for the implementation of back-shoring strategies in the UK and requires companies' attention prior to its repatriation.
\end{abstract}

Keywords: Back-shoring, Reshoring, Offshoring, Brexit

\title{
1. Introduction
}

International Location Decisions (ILDs) can be defined as 'a macro-level decision made by a firm, to pinpoint the geographic location of a partly or fully owned facility from a set of international alternatives' (Schmidt et al., 2017, pp 704). They represent an important issue in operations management and continue to be of significant importance to both practitioners and scholars (Tate et al., 2009; Tsimiklis \& Makatsoris 2019, Huq et al. 2016). Since the early 1980s, the most widespread approach to ILDs, especially in western countries, has been manufacturing offshoring towards low-cost countries (Mukherjee 2018; Theyel et al. 2018). This was boosted by an increase in international trade and economic liberalization in developing countries and has been primarily targeted to move low-skilled jobs to developing countries, also depicted by the so called 'smile curve' (Mudambi, 2008). However, with the advancement of information and communication technologies (ICT) and easier access to educational channels, the host countries were gradually able to provide more specialised production services (Moradlou and Backhouse 2016a). Meanwhile, the rising cost of energy and labour in low-cost countries, growing concern on environmental issues and theft of intellectual properties have been the major causes of diminishing offshoring benefits (Ellram et al., 2013; Manning, 2014; UNCTAD, 2015). According to Fine, over the past decade 'the 
big names at the end of the chain have come to realize that the lowest price can mean highest risk - and highest risk can mean high total costs' (2013, pp 6).

Whilst the offshoring trend started mainly with economic and cost-cutting aims (Joubioux and Vanpoucke, 2016; Waehrens et al. 2015), managers nowadays appraise ILDs by taking multiple factors such as strategy, risk management, flexibility and supply chain reliability into account. In other words, they do not solely rely on quantitative factors that trade off transport costs, scale economies and other cost-based variables (Tate, 2014; Stentoft et al. 2016). In recent years the number of offshoring failures has increased, partially due to underestimating the total cost associated with operating in a foreign location and the shift in customer expectations (Manning, 2014; Wiesmann et al. 2017). This has led to the emergence of a reverse trend mostly known as manufacturing 'reshoring'. The term has been used in the extant literature with several meanings ranging from the 'generic change of location with respect to a previous offshore country' (Fratocchi et al, 2014: 56) to a specific relocation with the emphasis on the home country (Gray et al, 2013; Ellram et al 2013; Barbieri et al, 2019). In this paper, we prefer to use the term back-shoring, based on previous studies done (Dachs et al, 2019; Di Mauro et al. 2018; Johansson et al. 2018). A study done by Wan et al. (2019) indicates that back-shoring is a phenomenon where each country has its own peculiarities and the decisions significantly differ in terms of industry, entry mode, firm size and motivations across each country. In a similar vein Bals et al. (2016) call for further research focusing on 'contingency issues' in back-shoring, in particular looking at firms' home country in comparison to other factors such as environmental and process-related contingencies. Therefore, it is important to conduct an in-depth study to investigate country specific factors in major economies in the EU to shed a light on back-shoring decisions and empirically analyse the relationship between home country and back-shoring decision. This paper aims to address the underpinning research gap identified by Wan et al. (2019) and Bals et al. (2016) which focuses on the role of home country in shaping companies' internationalisation paths.

Brennan et al. (2015, pp 1253) point out that 'the past three decades have seen the transformation of manufacturing involving its global dispersion and fragmentation. However, a number of recent developments (including the Covid-19 pandemics which had several negative impacts on Global Value Chains (Barbieri et al, 2020)) appear to suggest that manufacturing may be entering a new era of flux that will impact the configuration of production around the globe'. In this respect, the UK represents a unique and interesting context for back-shoring investigation since the country is currently undergoing a significant 
supply chain transformation due to Brexit uncertainties (The Economist, 2017; De Propris \& Bailey 2017). A study done by Roscoe et al. (2020) indicates that Brexit can impact companies in the UK in number of ways, from positioning supply chain assets, material and information flows to human resource availability and access to suppliers. According to a recent study done by Moradlou et al (2020a), managers are re-evaluating their supply chain location decisions to minimise the disruptions caused by Brexit as a geopolitical risk. Meanwhile a number of news articles highlight the new wave of back-shoring movement to the UK in different sectors such as plastics and railways (Financial Times, 2020; The Telegraph, 2020; Logistics manager 2020). This entails that manufacturing back-shoring is once more considered as a strategic decision and companies ought to make informed choices with respect to where they source or manufacture their products. Although the focus of this study is not to investigate Brexit, we believe that by highlighting the most critical variables affecting the previous back-shoring decisions making and implementation process in the UK, we will be able to identify what UK companies can learn for future relocation decisions. In doing so we base our research on the variables which have been identified for a general back-shoring decision making and implementation process by Boffelli and Johansson (2020).

Meanwhile the back-shoring strategy continues to receive governmental support in the UK. The UK was one of the very few countries in which government policies, aimed to support back-shoring strategies (Fratocchi et al., 2015a; De Backer et al., 2016). The back-shoring phenomenon received its first major attention when the prime minister of the UK, David Cameron at that time, called the UK the 're-shoring nation' at the World Economic Forum in Davos Switzerland (Groom and Parker, 2014). However, researchers have predominantly focused on the industrial policies adopted by the UK government whilst leaving the manufacturing challenges relatively unexplored (Bailey and De Propris, 2014a, 2014b). Our paper contributes to the literature by conducting multiple case studies, focusing specifically on the UK manufacturing sector, which provides a greater insight into back-shoring decisionmaking processes. By this we attempt to identify the underlying variables that affected the back-shoring decision making in the UK (Boffelli and Johansson 2020). Moreover, the paper identifies sector-specific variations in back-shoring decisions providing a more comprehensive data-set for validation and generalisability of the previous exploratory findings. Hence, we address the following two research questions:

RQ1: What were the main critical variables affecting the manufacturing back-shoring decisions making and implementation process for the UK companies? 
RQ2: What UK manufacturing companies could learn from the past back-shoring decisions?

The rest of the paper is structured as follows: in section 2, a systematic literature review is included to identify studies that investigate the home country-specific factors of back-shoring decisions both in Europe and the UK. In section 3, the research method is explained. Section 4 presents the findings from the eight selected case studies. More specifically, cross-case analysis is performed in order to develop theoretical propositions to be tested in future research. The concluding section summarises the limitations and practical implications.

\section{Literature review}

\section{Back-shoring in Europe}

Although, over the last 10 years, back-shoring has received considerable attention in Europe and the number of academic publication has increased (Barbieri et al, 2018; Stentoft et al, 2016c), studies focusing on UK industries are very limited. In order to develop a comprehensive theoretical framework for our case studies, a systematic literature review was conducted. In doing so, authors were able to: a) define the set of variables investigated in the extant literature to characterise the back-shoring phenomenon at the firms' home country; b) identify the existing literature focusing on the back-shoring phenomenon in the UK. As a result, peer reviewed Scopus indexed journal articles published in the English language up to $31^{\text {st }}$ December 2019 were investigated. The following key terms in title, abstract and keywords were used: a) "reshor*”; b) "re-shor*"; c) "backshor*"; d) "back-shor*”; e) "back-reshor*”; f) "back-sourc*"; g) "backsourc*". Moreover, the following exclusion criteria were implemented:

- Studies focusing on industries other than manufacturing (e.g., information and communication technologies);

- Studies in which the searched terms are used to refer to a different concept;

- Studies referring to functions other than operations (e.g., human resources and research and development (R\&D).

In total, 132 journal articles were found, of which 33 refer to the investigation of backshoring in at least one European country (see Appendix 1). The analysis was done to understand what variables have been already used to investigate back-shoring evidence in European countries. To do this, we referred to the Boffelli and Johansson (2020) framework which allows 
to analyse both offshoring and back-shoring decision making and implementation process. More specifically, we found sampled documents analysed the following six elements: drivers, enabling factors, barriers, outcomes, governance mode, degree of reshoring. The review of sampled documents shows that 29 out of 33 articles specifically investigate the drivers behind back-shoring decisions at the home country. Following this, the second widely studied issue is the enabling factors (11 out of 33), that is, to facilitate the back-shoring strategy (e.g., advent of industry 4.0). The third issue was the outcome (10 out of 33) of the back-shoring decision. It can be noticed that the governance mode after the implementation of back-shoring (6 studies), and barriers to back-shoring implementation (five) have received nominal attention in the literature. Furthermore, the extent literature tends to neglect the degree of back-shoring (Baraldi et al, 2020), that is, the amount of repatriated activities compared to those offshored previously (only three studies). The above review highlights the main areas studied in the extant literature in the context of back-shoring home country. Using these set of variables, we will look at the back-shoring studies in the UK to further investigate current state of literature and outline the gap.

\section{Back-shoring in the UK}

When considering the 33 sampled articles, we found that 11 journal articles specifically address the back-reshoring phenomenon in the UK (Table 1). Although these studies mainly adopt semi-structured interviews (four) and single case studies (four), the insight they provide is limited and does not adequately cover all the dimensions of the back-shoring decision making and implementation process (e.g., including drivers and barriers). It can also be noted that three of the four case studies focus only on one sector (clothing/textile). Our review also indicates that UK-based studies mainly concern the motivations for back-shoring and neglect some of the urgent issues such as governance modes, degree of back-shoring, outcomes and barriers which we believe are useful insights for decision making post-Brexit.

Table 1, Journal articles studying the back-shoring decision in the UK

\begin{tabular}{|c|c|c|c|c|c|c|c|c|c|}
\hline Author(s) & Year & $\begin{array}{c}\text { Research } \\
\text { methodology }\end{array}$ & Industry & Drivers & $\begin{array}{c}\text { Enabling } \\
\text { factors }\end{array}$ & Barriers & Outcomes & $\begin{array}{l}\text { Gover } \\
\text { nance } \\
\text { mode }\end{array}$ & $\begin{array}{c}\text { Degr } \\
\text { ee of } \\
\text { resho } \\
\text { ring }\end{array}$ \\
\hline Ashby, A & 2016 & 1 Case study & Clothing & $x$ & $x$ & $x$ & & $x$ & $x$ \\
\hline $\begin{array}{c}\text { Bailey, D., De } \\
\text { Propris, L. }\end{array}$ & 2014 & $\begin{array}{l}\text { Semi-structured } \\
\text { interview }\end{array}$ & Automotive & $x$ & & $x$ & & & \\
\hline
\end{tabular}




\begin{tabular}{|c|c|c|c|c|c|c|c|c|c|}
\hline $\begin{array}{c}\text { Bailey, D., De } \\
\text { Propris, L. }\end{array}$ & 2014 & $\begin{array}{l}\text { Semi-structured } \\
\text { interview }\end{array}$ & Automotive & $x$ & & $x$ & & & \\
\hline $\begin{array}{r}\text { Benstead, } \\
\text { A.V., Stevenso } \\
\text { n, M., Hendry, } \\
\text { L.C. }\end{array}$ & 2017 & 1 Case study & $\begin{array}{l}\text { Home } \\
\text { textile }\end{array}$ & $x$ & $x$ & $x$ & $x$ & $\mathrm{x}$ & $x$ \\
\hline $\begin{array}{r}\text { Moradlou, H., } \\
\text { Backhouse, } \\
\text { C.J. }\end{array}$ & $2016 b$ & 1 Case study & Electronics & $x$ & & & $x$ & & \\
\hline $\begin{array}{r}\text { Moradlou, H., } \\
\text { Backhouse, } \\
\text { C.J. } \\
\text { Ranganathan, } \\
R .\end{array}$ & 2017a & $\begin{array}{l}\text { Semi-structured } \\
\text { interview }\end{array}$ & $\begin{array}{l}\text { Several } \\
\text { industries }\end{array}$ & $X$ & $x$ & & & & \\
\hline $\begin{array}{r}\text { Moradlou, } \\
\text { H., Tate, W. }\end{array}$ & 2018 & $\begin{array}{l}\text { Semi-structured } \\
\text { interview }\end{array}$ & $\begin{array}{l}\text { Several } \\
\text { industries }\end{array}$ & $x$ & $x$ & & & & \\
\hline $\begin{array}{l}\text { Robinson, } \\
\text { P.K., Hsieh, L. }\end{array}$ & 2016 & 1 Case study & Clothing & $X$ & $x$ & $X$ & $X$ & & \\
\hline $\begin{array}{r}\text { Srai, J.S., \& } \\
\text { Ané, C. }\end{array}$ & 2016 & Secondary data & $\begin{array}{l}\text { Several } \\
\text { industries }\end{array}$ & $x$ & & & & & \\
\hline $\begin{array}{l}\text { Theyel, G., } \\
\text { Hofman, K., } \\
\text { Gregory, M. }\end{array}$ & 2018 & Survey & $\begin{array}{l}\text { Several } \\
\text { industries }\end{array}$ & $X$ & & & $X$ & & \\
\hline $\begin{array}{c}\text { Vanchan, V., } \\
\text { Mulhall, R., } \\
\text { Bryson, J. }\end{array}$ & 2018 & Secondary data & $\begin{array}{l}\text { Several } \\
\text { industries }\end{array}$ & $x$ & & & & & \\
\hline
\end{tabular}

In order to shed further light on the back-shoring phenomenon in the UK, further content analysis was conducted to specifically identify the drivers, enabling factors, barriers and outcomes (see Table 2). Looking at the motivations/drivers for back-shoring, it can be noted that poor quality and the need to reduce lead times and costs (both in terms of logistic activities and coordination) were among the top motivations. It was also observed that the made in effect plays an important role in textile industries. Moreover, in two of the four case studies, sustainability was cited as one of the most pertinent drivers. This is consistent with recent findings in the extant literature (Orzes and Sarkis, 2019; Fratocchi \& Di Stefano, 2019). Among enabling factors, long-term relationships with local suppliers and availability of skilled workers and suppliers are cited (Moradlou and Backhouse, 2017a; Robinson and Hsieh, 2016). This finding is partially in contradiction with other studies listing the lack of skills as a barrier to back-shoring to the UK (Bailey and De Propris, 2014a, b; Benstead et al, 2017). Finally, in terms of outcomes, improvement of product quality and higher visibility and control over the supply chain are the most cited benefits. 
Table 2, Drivers, enabling factors, barriers and outcomes of UK back-shoring decisions

\begin{tabular}{|c|c|c|c|c|c|c|c|c|c|c|c|}
\hline & Investigated issues & & & & & Sou & & & & & \\
\hline & & Ashby, A & $\begin{array}{l}\text { Bailey, } \\
\text { D., De } \\
\text { Propris, } \\
\quad \text { L. }\end{array}$ & $\begin{array}{l}\text { Bailey, } \\
\text { D., De } \\
\text { Propris, } \\
\quad \text { L. }\end{array}$ & $\begin{array}{l}\text { Benstead, } \\
\text { A.V., Stevenson, } \\
\text { M., Hendry, L.C. }\end{array}$ & $\begin{array}{l}\text { Moradlou, } \\
\text { H., } \\
\text { Backhouse, } \\
\text { C.J. }\end{array}$ & $\begin{array}{c}\text { Moradlou, H., } \\
\text { Backhouse, } \\
\text { C.J., } \\
\text { Ranganathan, } \\
\text { R. }\end{array}$ & $\begin{array}{l}\text { Moradlou, } \\
\text { H., Tate, } \\
\text { W. }\end{array}$ & $\begin{array}{l}\text { Robinson, } \\
\text { P.K., } \\
\text { Hsieh, L. }\end{array}$ & $\begin{array}{c}\text { Theyel, } \\
\text { G., } \\
\text { Hofman, } \\
\text { K., } \\
\text { Gregory, } \\
\text { M. }\end{array}$ & $\begin{array}{c}\text { Vanchan, } \\
\text { V., } \\
\text { Mulhall, } \\
\text { R., } \\
\text { Bryson, J. }\end{array}$ \\
\hline & & 2016 & $2014 a$ & $2014 b$ & 2017 & $2016 b$ & $2017 a$ & 2018 & 2016 & 2018 & 2018 \\
\hline & $\begin{array}{l}\text { Poor quality of offshored } \\
\text { products }\end{array}$ & & $\mathrm{x}$ & & $\mathrm{x}$ & $\mathrm{x}$ & $\mathrm{x}$ & & & $x$ & \\
\hline & $\begin{array}{l}\text { Transportation and logistics } \\
\text { costs }\end{array}$ & & $x$ & $x$ & $x$ & & $x$ & & & & \\
\hline & Lead times reduction & & $x$ & & $x$ & $\mathrm{x}$ & $\mathrm{x}$ & & & & \\
\hline & $\begin{array}{l}\text { Communication/coordination } \\
\text { and monitoring costs for } \\
\text { offshored activities }\end{array}$ & & & & $x$ & $x$ & $x$ & & $x$ & & \\
\hline & Exchange risk fluctuations & & $x$ & $x$ & $x$ & & & & & & \\
\hline$\grave{\Phi}$ & $\begin{array}{l}\text { Increasing labour costs at the } \\
\text { home country }\end{array}$ & & $x$ & $\mathrm{x}$ & $x$ & & & & & & \\
\hline 㝘 & $\begin{array}{l}\text { Co-location of } \\
\text { R\&D/Design/Manufacturing }\end{array}$ & & & & $x$ & & & & & $x$ & $x$ \\
\hline & Responsiveness & & & & $x$ & & $x$ & $x$ & & & \\
\hline & $\begin{array}{l}\text { Intellectual property better } \\
\text { protection }\end{array}$ & & & & $\mathrm{x}$ & & & & & $\mathrm{x}$ & $x$ \\
\hline & Made in effect & & & & $x$ & & & & $x$ & & $x$ \\
\hline & Awareness of costs of s.c. & & $x$ & $x$ & & & & & & & \\
\hline & Sustainability & $x$ & & & $x$ & & & & & & \\
\hline & Need of a rapid turnover & & $x$ & & & & & & & & \\
\hline & Service quality level & & $x$ & & & & & & & & \\
\hline & Cost reduction & & $x$ & & & & & & & & \\
\hline
\end{tabular}


Improving delivery

performance

Availability of skilled

workforce

Cultural difference

home/host country

Labour productivity

improvement at the home

country

Duties on imported goods

Availability of spare capacity

onshore

Flexibility based

Market based

Risk based

Speed based

Simplify logistics activities

Avallability of skil

Availability of skilled workers

Access to finance

Home country labour costs

$\cong$ Higher production costs at

the home country

Energy costs

Raw materials costs and

availability

Regulations

on s.c.

¿ Responsiveness

วิ Innovativeness

Lead times reduction

$\begin{array}{ll}x & x \\ x & x\end{array}$

$\mathrm{x}$

Lower logistic costs 
Reduced carbon footprint

$X$

Co-location of

R\&D/Design/Manufacturing

Relationships with home

X

country suppliers

Availability of skilled

workers/suppliers at the

home country

는 In-house training (to

$\underset{\overbrace{}}{\leftarrow}$ overcome skill shortage)

@o Target market upgrade

Availability of production

w capacity at the home country

IT solutions for SCM

Re-configurability of

$\mathrm{X}$

manufacturing equipment

Additive manufacturing 


\section{Research methodology}

Considering the back-shoring being a contemporary phenomenon, about which little is known and over which the researchers had little control, and given the small amount of research investigating the decision making and implementation process in the UK, a case study methodology was selected (Yin, 2014). A multiple case study approach was employed to inductively explore the back-shoring decision and develop propositions as outputs (Patton, 2002). A key strength of the case study approach is that it allows the phenomenon to be studied in its real-life context which, in this study, is particularly pertinent as the boundaries between the phenomena under study (back-shoring of manufacturing), and the wider context, is not clearly evident. In this section the three main stages of research design are described.

\subsection{Stage 1: Define and Design}

The first stage includes case selection and design of the data collection protocols. Case selection uses purposeful sampling to access companies who have experienced the phenomenon of interest and expected to provide independent corroboration of the results (Patton, 2014; Yin, 2014). Hence eight companies were selected (Ellram 1996) from the domain of UK manufacturing companies, each representing an individual case study, based on the criteria that each company has back-shored at least part of its manufacturing. The unit of analysis in this study is the company's back-shoring decision. The case companies span a range of industry sectors including automotive, furniture, computer, garment, laundry products and apparel and are also diverse in terms of their size, including SMEs and large companies (shown in Table 3). This improves the generalisability of findings and enables a cross sector comparison to be performed. Such selection criteria for the case samples allow the authors to synthesise the past back-shoring experience in the UK that can be useful for new ILD decisions post-Brexit. According to Moradlou et al. (2020a), the impacts of Brexit on manufacturing supply chain location decisions will not be consistent across different sectors. Therefore, a cross-case comparison can potentially enable companies to utilise relevant findings and make informed decisions with respect to back-shoring outcomes and barriers. 
Table 3, Case companies

\begin{tabular}{|c|c|c|c|c|c|c|c|c|}
\hline & ShoeCo (A) & SofaCo (B) & BedCo (C) & AutoCo (D) & RubberCo (E) & LaundryCo (F) & ComputerCo (G) & GarmentCo $(\mathrm{H})$ \\
\hline Industry & Fashion & Furniture & Furniture & Automotive & Rubber components & Laundry products & Computer & Apparel \\
\hline Employees & 24 & over 250 & over 250 & 55 & 50 & 36 & 45 & over 250 \\
\hline $\begin{array}{l}\text { Respondent's } \\
\text { role in the } \\
\text { company }\end{array}$ & $\begin{array}{l}\text { Managing director } \\
\text { and founder }\end{array}$ & $\begin{array}{l}\text { Managing director of } \\
\text { company's UK retail } \\
\text { services }\end{array}$ & $\begin{array}{l}\text { Managing director } \\
\text { of company's UK } \\
\text { manufacturing } \\
\text { service }\end{array}$ & $\begin{array}{l}\text { Sales and Marketing } \\
\text { director }\end{array}$ & Operating director & $\begin{array}{l}\text { Co-founder and } \\
\text { managing director }\end{array}$ & $\begin{array}{l}\text { Share holder and } \\
\text { managing director }\end{array}$ & $\begin{array}{l}\text { Managing } \\
\text { director }\end{array}$ \\
\hline $\begin{array}{l}\text { Year of } \\
\text { establishment }\end{array}$ & 2008 & 1970 & 1986 & 1993 & 1935 & 2008 & 2003 & 1992 \\
\hline $\begin{array}{l}\text { Products } \\
\text { Characteristics }\end{array}$ & $\begin{array}{l}\text { Manufacturing } \\
\text { shoes and relevant } \\
\text { accessories. Three } \\
\text { product brands. }\end{array}$ & $\begin{array}{l}\text { Multinational } \\
\text { producing } \\
\text { upholstered furniture } \\
\text { (e.g., settees and } \\
\text { chairs) equally } \\
\text { distributed between } \\
\text { customised and } \\
\text { standard products. }\end{array}$ & $\begin{array}{l}\text { Beds with its own } \\
\text { brand ( } 50 \% \text { of total } \\
\text { sales) and sales of } \\
\text { other third party } \\
\text { companies selling } \\
\text { similar products }\end{array}$ & $\begin{array}{l}\text { Differentiated set of } \\
\text { automotive } \\
\text { components (e.g., } \\
\text { harnesses, } \\
\text { connectors, lighting). } \\
\text { It also offers a } \\
\text { prototyping service. }\end{array}$ & $\begin{array}{l}\text { Wide range of } \\
\text { rubber-made } \\
\text { products (e.g., } \\
\text { hydraulic and } \\
\text { pneumatic seals) } \\
\text { produced through } \\
\text { moulding and/or } \\
\text { extrusion } \\
\text { technologies. }\end{array}$ & $\begin{array}{l}\text { Produces eco-friendly } \\
\text { household and laundry } \\
\text { products. Offering a } \\
\text { portfolio of } 32 \text { types of } \\
\text { products. }\end{array}$ & $\begin{array}{l}\text { Produces } \\
\text { customised } \\
\text { computer } \\
\text { components (80- } \\
85 \% \text { of total sales) } \\
\text { and standard } \\
\text { products (15\%- } \\
20 \% \text { ). }\end{array}$ & $\begin{array}{l}\text { Produces luxury } \\
\text { garment and } \\
\text { apparel goods } \\
\text { for the high-end } \\
\text { market. }\end{array}$ \\
\hline $\begin{array}{l}\text { Market } \\
\text { segments and } \\
\text { distribution } \\
\text { channels }\end{array}$ & $\begin{array}{l}\text { Distribution } \\
\text { channels: retailers } \\
\text { ( } 80 \% \text { total } \\
\text { turnover); export } \\
\text { through distributors } \\
(15 \%) \text {; on-line stores } \\
(5 \%)\end{array}$ & $\begin{array}{l}\text { Target market: } \\
\text { medium-end. Sales } \\
\text { through its own } \\
\text { shops }\end{array}$ & $\begin{array}{l}\text { Target market: } \\
\text { medium-end. Sales } \\
\text { through its own } \\
\text { shops }\end{array}$ & $\begin{array}{l}\text { The company directly } \\
\text { refers to car } \\
\text { manufacturers (e.g., } \\
\text { Land Rover, Jaguar } \\
\text { and Bentley). }\end{array}$ & $\begin{array}{l}\text { The company sales } \\
\text { at the trade counter } \\
\text { and online. }\end{array}$ & $\begin{array}{l}\text { The company exports } \\
85 \% \text { of the total } \\
\text { turnover. The UK } \\
\text { turnover is made through } \\
\text { direct sales, retail } \\
\text { wholesalers and TV } \\
\text { shopping. }\end{array}$ & $\begin{array}{l}25 \% \text { of total sales } \\
\text { is obtained on- } \\
\text { line. The rest } \\
\text { through B2B } \\
\text { approach }\end{array}$ & $\begin{array}{l}\text { The company } \\
\text { has an own } \\
\text { brand ( } 1 / 3 \text { of } \\
\text { total sales) and } \\
\text { produces for } \\
\text { other luxury } \\
\text { brands. }\end{array}$ \\
\hline
\end{tabular}




\subsection{Stage 2: Prepare and Collect}

Data collection led to the preparation of individual case reports. Each case was developed with the aid of multiple data collection methods, comprising semi-structured interviews, and secondary data from company publications. In total, eight high quality interviews, ranging between 45-60 minutes per interview, were conducted targeting the key informants within the companies such as Chief Executive Officers (CEO) and Managing Directors (MD). As a result of accessing a highly qualified and reliable source of information within each case, one interview per case was deemed to be sufficient and all the required data were captured (Ellram 1996). We also developed a preliminary protocol based on previous research and existing literature using the recommendation by Yin (2014). The protocol consisted of research questions, research design and methodology and interview questions (see Appendix 2) (Ellram 1996). The interview questions mainly investigated the companies' experience with offshoring and back-shoring decisions and their drivers and barriers. The interviews were recorded, transcribed and manually coded; then, in order to improve construct validity and reduce observer bias, the outcomes of interviews were sent to the respondents for validation (Eisenhardt, 1989).

\subsection{Stage 3: Analyse and Conclude}

In order to analyse the sampled case studies, a methodology was adopted inspired by the Sequential Incident Technique (SIT) (Stauss and Weinlich's, 1997), since it allows the collection of data on both the company's ILDs - its offshoring as well as back-shoring. According to the SIT approach, the back-shoring path is conceptualised as divided into three main phases. The first refers to the time before the offshoring decision; the second begins after the relocation of production activities to a host country; and the third phase starts with the execution of the back-shoring strategy to the home country. Our systematic literature review points out several issues that are investigated when back-shoring decisions are made. However, it also indicates a lack of structured approach to capture all the relevant information. In this respect, we adopt and further develop the ' $5 \mathrm{~W} \& 1 \mathrm{H}$ ' approach elements introduced by Barbieri et al. (2018). The $5 \mathrm{~W} \& 1 \mathrm{H}$ approach can be defined as follows: a) Who: refers to the characteristics of the target company and its external environment (e.g., size, industry); b) Why: concerns the motivation/drivers behind the relocation; c) What: regards the content of the decision, i.e., what type of production activity/product line has been relocated (selectivity in terms of width or depth); d) When: refers to the timing of the back-shoring decision; e) Where: 
refers to the home and host country location; f) How: refers to the decision-making and implementation phases of back-shoring. In particular the adopted governance mode (insourcing vs. out-sourcing). Following Boffelli and Johansson (2020), the 5W\&1H approach is further developed by adding two additional factors, back-shoring outcomes and barriers, since the above framework does not provide post-implementation perspectives. This framework can be used as a possible tool to conduct research on relocation of manufacturing activities to the home country where post-back-shoring insights are captured. The use of the SIT combined with $5 \mathrm{~W} \& 1 \mathrm{H}$ approach allows researchers to compare the outcomes of the two types of ILD (off-shoring and back-shoring) (Heikkilä et al., 2018a, b; Johanson and Ohlager, 2018; Johanson et al., 2018).

Scrutiny of the data involved within-case analysis and cross-case pattern searching (Eisenhardt, 1989) followed by identification of research contributions to theory and practice. After investigating companies' offshoring and back-shoring processes, cross-case analysis using the $5 \mathrm{~W} \& 1 \mathrm{H}$ approach was conducted resulting in two cross-comparison tables and one matrix. The first table focuses on four of the five Ws (excluding 'Why') and the How issue. Meanwhile the cross-comparison matrix expands on the Why issues which capture the offshoring and backshoring motivations according to two dimensions. The matrix is developed according to the Fratocchi et al. (2016) framework which classifies motivations according to the firm's aims (cost efficiency vs customer perceived value) and relevant environment factors (internal vs external) for offshoring and back-shoring motivations (as shown in Figure. 1). Finally, the last cross-comparison table presented in findings section highlights the outcomes and encountered barriers during the back-shoring process. 


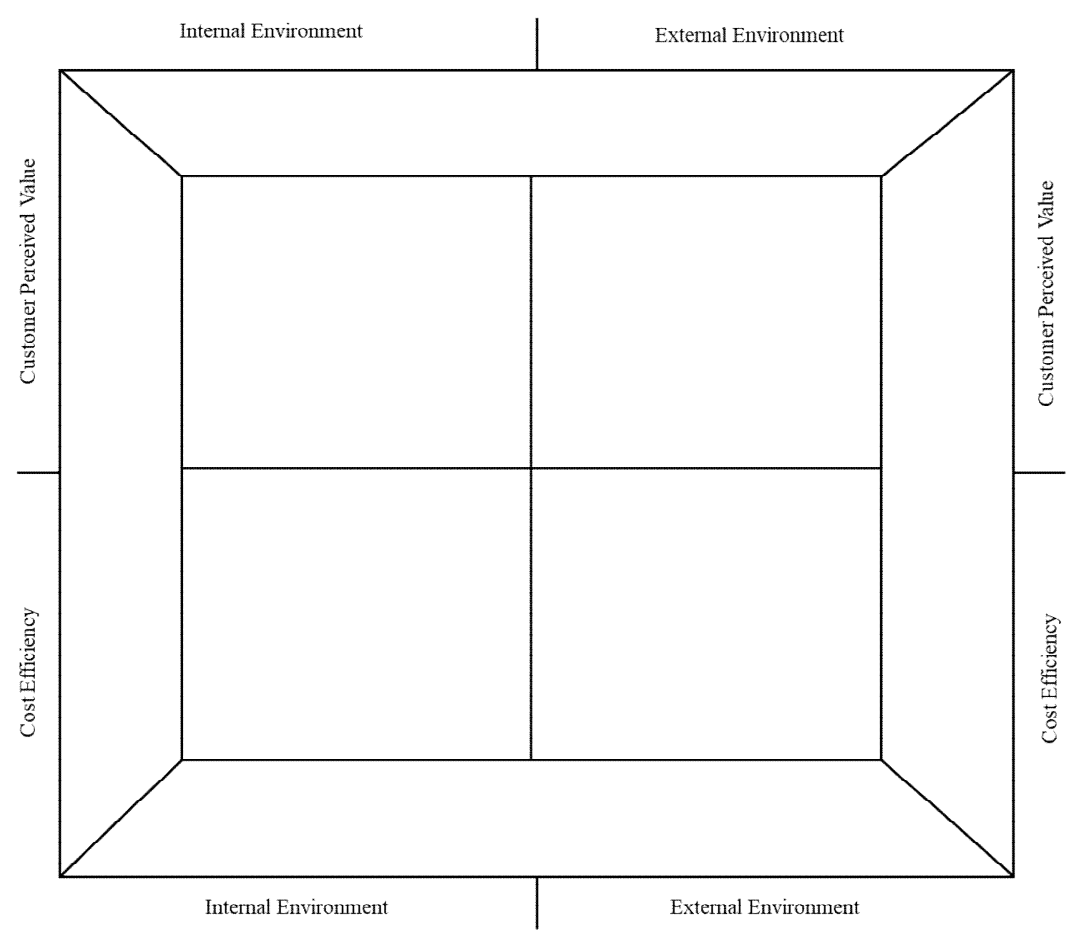

Figure. 1, Offshoring and Back-shoring drivers' framework (Fratocchi et al. 2016)

\section{Findings}

The findings which emerged from the eight case studies are summarised in three crosscomparison tables. Table 4 provides an overview of "who", "what", "where", "when" and "how" related issues. In other words, it identifies the types of businesses investigated, the offshoring destinations, timeline for their decision making process (both for offshoring and back-shoring), and their approach with respect to the production governance mode (in-house vs outsourced production). Figure 2 shows the cross-comparison for the main motivations behind the offshoring and back-shoring decisions using the Fratocchi et al. (2016) framework. Finally, Table 5 presents the findings in terms of the outcomes of offshoring and back-shoring decisions and the barriers faced by companies as they returned operations to the UK.

As shown in Table 4, the case companies represent three different types of offshoring strategies. The first group is represented by companies who have offshored the production operations for at least two years (of out of eight cases). The second category comprises the companies who were initially registered in the UK but set up their production in a foreign location and operated offshore for more than one year; we refer to such companies as "born offshored" (two out of eight cases). After experiencing operational difficulties, these companies decided to repatriate their manufacturing activities to the UK. The third category refers to the companies who conducted offshoring trials over a period of less than a year, 
assessing the opportunities and challenges of offshore operations in a low cost country and then decided to maintain their operations in the UK.

The findings also indicate various governance modes implemented when the companies decided to relocate their operations. The vast majority of the companies who initially insourced their operations switched to an out-sourcing mode as they engaged in the offshoring process. However, while back-shoring they switched back to an in-sourcing approach in order to gain more control over production. With this in mind, the Managing Director at BedCo stated:

'We realised that it is difficult to manage long supply chains; however, with shorter supply chains we can control the operations and be able to compete in the market'. Managing

\section{Director at BedCo}

Figure 2 presents the motivations for both offshoring and back-shoring. It breaks down the drivers according to the framework proposed by Fratocchi et al. 2016. Among the offshoring motivations, respondents listed the following factors: cost and productivities of the skilled labour, access to cheaper resources and materials, host country supply base, availability of skilled workforce in the host country, access to know-how, time to market and capacity bottle-neck in the home country. On the other hand, a wider range of motivations were recorded for the back-shoring decision. In the majority of the case companies the primary reason behind back-shoring was related to lead-time and flexibility. This is consistent across different industries where the results show significant consensus; however, secondary motivations tend to vary depending on the characteristics of the companies (industry sector, size of the companies, and mode of offshoring). The following indicate a number of comments which emphasise lead time issues:

'The manufacturing lead time from receipt to order was two months. On top of that another two months shipping time making it total four months lead time for one order. The timeline was too long. The torch is a custom option on every customer's order. If the torch is not available, it stops the entire transaction for the sale of the car; therefore, delivery reliability and lead time were absolutely critical.' Sales and Marketing director at AutoCo

'When producing in the home country or in Europe, the standard delivery time is within 24 hours. If produced in the Far East, merely the shipping time will take four to six weeks. When there was a quality problem, the company could not realise that until the goods arrived; therefore, it was very difficult to solve the problem. The company had to send the products 
back for suppliers to check the goods. This led to a further 12-week delay.' Operating director at RubberCo

'Production has to work in conjunction with design. It has to change attitude to accommodate the new product. In the past, there was only two seasons. Autumn Winter, and

Spring Summer. Now there are at least six seasons: early-summer, mid-summer, latesummer, and so on. The company must constantly innovate and launch new products all the time. For Chinese factories, the distance to the market may be a problem. Produce in small quantity and the ability to switch to different product quickly may not be easy. In addition, colour can change season to season. Factories must have a very flexible dying technique so that they can change quickly for small quantities. It is much easier in practical terms to produce in the UK.' Managing director at GarmentCo

However, some secondary motivations were also identified which are more industry specific:

They [customers] pay a high price for the products and they want the label to be 'made in UK' not 'made in China'. Also, the Chinese market is growing and becoming a big market for European products. Chinese customers become wealthier and they want the best. They don't want to feel they are buying something from Europe but made in China.' Managing director at GarmentCo

'We are making eco-friendly product we are eco-friendly Company that it just didn't feel right to source thing half way around the world just didn't make sense.' Co-founder and managing director at LaundryCo

Finally, the cross comparison in Table 5 highlights the final outcome of the offshoring and back-shoring decisions as well as the barriers that companies faced after back-shoring. It is notable that the outcomes of the ILDs favourably changed once companies transferred their operations back to the UK. A significant improvement was found to be the reduction in production lead-time which is consistent across various sectors. Higher working capital due to long lead times was also observed as an outcome of offshoring. According to the Managing Director at SofaCo:

'For customised products [that accounts for around 50\% of total sales], the typical lead time was 12 to 14 weeks. However, customers don't want to wait, they want to have the products in 21 to 28 days. From our own factory, we can achieve the three to four-week lead time.' 
Some companies also indicated that they managed to establish a better collaboration with local suppliers and set up a better payment arrangement due to proximity and trust with local suppliers. Co-founder and managing director at LaundryCo stated that having to meet the advanced payment requirements and considering the long lead times, during offshoring, had a negative impact on the firm's cash flow. In addition to the above outcomes, companies can overcome the challenges imposed by minimum order quantity (MOQ) when doing the operations in-house. In this respect the Managing Director at BedCo mentioned that once the production was repatriated, foreign suppliers were replaced by utilising internal capacity at the company where MOQ limitation could be addressed. Moreover, at AutoCo, the MOQ imposed by Chinese suppliers was too high when compared to the torch demand variability over time. This, in turn, obliged AutoCo to increase the stock level or to ship goods from China via air transport, further increasing transportation costs. In addition, interestingly, the two 'born offshored companies exhibited a very similar offshoring outcome to the rest of the sampled case studies.

Looking at Table 5 and Figure 2, it can be established that a number of motivations overlap with the outcomes of back-shoring which we believe it could partially be due to postrationalisation. With respect to the barriers, all participants stressed the shortage of skilled workforce in the UK to be the main concern for back-shoring cases. In some scenarios developing new production capacity was also noted to be a secondary barrier. The Operating director at RubberCo explained that:

'It was a difficult task to find right skilled personnel to operate expensive machines in the production line.' Operating director at RubberCo 
Table 4, Cross-case comparison (4W\&1H)

\begin{tabular}{|c|c|c|c|c|c|c|c|c|c|c|c|c|}
\hline \multirow[t]{2}{*}{ Who } & \multirow[t]{2}{*}{ Where } & \multicolumn{4}{|c|}{ What } & \multicolumn{3}{|c|}{ When } & \multicolumn{4}{|c|}{ How } \\
\hline & & Home & Host & Home & Selectivity & Offshoring & Reshoring & Duration & Home & Host & Home & Changes \\
\hline $\begin{array}{c}\text { ShoeCo } \\
\text { Footwear (A) }\end{array}$ & China & $\begin{array}{c}\text { Born } \\
\text { offshored }\end{array}$ & $\begin{array}{l}3 \text { product } \\
\text { brand }\end{array}$ & 1 product brand & $\begin{array}{l}\text { Selectivity in } \\
\text { terms of width } \\
\text { (reshoring) }\end{array}$ & 2008 & 2013 & 5 & Born offshored & OUT & OUT & None \\
\hline $\begin{array}{l}\text { SofaCo Furniture } \\
\text { (B) }\end{array}$ & China & All products & All products & All products & None & 2009 & 2011 & 2 & IN & OUT & IN & YES \\
\hline $\begin{array}{l}\text { BedCo Furniture } \\
\text { (C) }\end{array}$ & Croatia & All products & All products & All products & None & 2008 & 2013 & 5 & IN & OUT & IN & YES \\
\hline $\begin{array}{c}\text { AutoCo } \\
\text { Automotive } \\
\text { components (D) }\end{array}$ & China & $\begin{array}{l}\text { Several } \\
\text { production } \\
\text { lines }\end{array}$ & 1 product line & 1 product line & $\begin{array}{l}\text { Selectivity in } \\
\text { terms of width } \\
\text { (offshoring) }\end{array}$ & 2011 & 2013 & 2 & IN & OUT & IN & YES \\
\hline $\begin{array}{c}\text { RubberCo } \\
\text { Automotive (E) }\end{array}$ & China & $\begin{array}{l}\text { All product } \\
\text { lines }\end{array}$ & Trial projects & All product lines & $\begin{array}{c}\text { Trial offshoring } \\
\text { project }\end{array}$ & 2000 & 2000 & $\begin{array}{l}\text { Less than a } \\
\text { year }\end{array}$ & IN & OUT & IN & YES \\
\hline $\begin{array}{l}\text { LaundryCo } \\
\text { Laundry } \\
\text { products (F) }\end{array}$ & $\begin{array}{l}\text { Far East } \\
\text { Vietnam }\end{array}$ & $\begin{array}{c}\text { Born } \\
\text { offshored }\end{array}$ & $\begin{array}{c}\text { All } \\
\text { production } \\
\text { phases }\end{array}$ & $\begin{array}{l}\text { All production } \\
\text { phases }\end{array}$ & None & 2008 & 2011 & 3 & Born offshored & OUT & $\begin{array}{c}\text { OUT } \\
\text { (Production) } \\
\text { \& IN (Final } \\
\text { assembling) }\end{array}$ & Partially \\
\hline $\begin{array}{l}\text { ComputerCo } \\
\text { Computer } \\
\text { systems (G) }\end{array}$ & China & $\begin{array}{c}\text { All } \\
\text { production } \\
\text { phases }\end{array}$ & $\begin{array}{c}\text { Selected } \\
\text { production } \\
\text { phases (no } \\
\text { assembling) }\end{array}$ & $\begin{array}{l}\text { All production } \\
\text { phases }\end{array}$ & $\begin{array}{l}\text { Selectivity in } \\
\text { terms of depth } \\
\text { (offshoring) }\end{array}$ & 2006 & 2011 & 5 & $\begin{array}{l}\text { OUT (component } \\
\text { production) \& IN } \\
\text { (assembling) }\end{array}$ & $\begin{array}{c}\text { OUT } \\
\text { (component } \\
\text { production) }\end{array}$ & IN & YES \\
\hline $\begin{array}{c}\text { GarmentCo } \\
\text { Cashmere made } \\
\text { garment }(\mathrm{H})\end{array}$ & China & $\begin{array}{c}\text { All } \\
\text { production } \\
\text { phases }\end{array}$ & Trial orders & $\begin{array}{l}\text { All production } \\
\text { phases }\end{array}$ & $\begin{array}{c}\text { Trial offshoring } \\
\text { project }\end{array}$ & 2001 & 2001 & $\begin{array}{l}\text { Less than a } \\
\text { year }\end{array}$ & IN & OUT & IN & YES \\
\hline
\end{tabular}




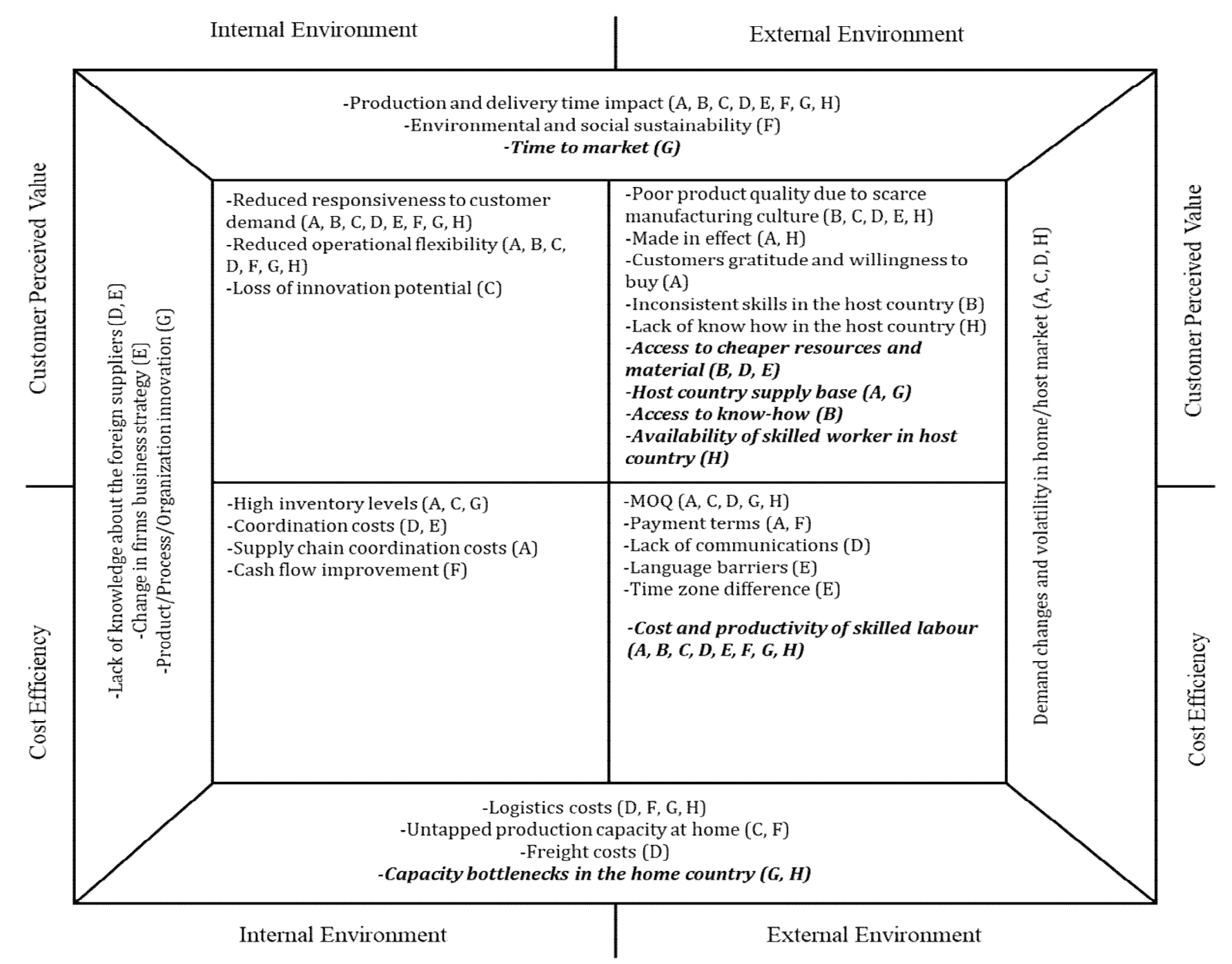

Figure 2, Offshoring drivers (shown in bold font) and back-shoring drivers (shown in normal font) based on Fratocchi et al (2016) framework 
Table 5, Back-shoring Outcomes and Barriers

\begin{tabular}{|c|c|c|c|}
\hline \multirow[t]{2}{*}{ Case Company } & \multicolumn{2}{|c|}{ Outcome } & \multirow[t]{2}{*}{ Barriers } \\
\hline & Host & Home & \\
\hline $\begin{array}{c}\text { ShoeCo } \\
\text { Footwear (A) }\end{array}$ & $\begin{array}{l}\text { - Lead time } 6-8 \text { weeks } \\
\text {-Higher working capital } \\
\text { (Minimum order quantity + } \\
\text { payment in advance) } \\
\text {-Higher logistics cost } \\
\text {-Reduced production costs }\end{array}$ & $\begin{array}{l}\text {-Lead time reduced by } 20 \% \\
\text {-Reduction of net working capital } \\
\text {-Reduced logistics costs } \\
\text {-Turnover has been tripled } \\
\text { Better payment arrangements }\end{array}$ & $\begin{array}{l}\text {-Availability of skilled } \\
\text { people at the home } \\
\text { country (in case of future } \\
\text { sales growth) }\end{array}$ \\
\hline $\begin{array}{c}\text { SofaCo } \\
\text { Furniture (B) }\end{array}$ & $\begin{array}{l}\text {-Lead time } 12-24 \text { weeks } \\
-12 \% \text { non-compliant products } \\
\text {-Higher working capital }\end{array}$ & $\begin{array}{l}\text {-Lead time } 3-4 \text { weeks } \\
-15 \% \text { reduction of customer } \\
\text { complaints } \\
\text {-Networking capital reduced }\end{array}$ & $\begin{array}{l}\text {-Need to develop } \\
\text { production planning skills } \\
\text {-Availability of skilled } \\
\text { people }\end{array}$ \\
\hline $\begin{array}{c}\text { BedCo } \\
\text { Furniture (C) }\end{array}$ & $\begin{array}{l}\text {-Lead time 3-4 weeks } \\
\text {-Higher working capital }\end{array}$ & $\begin{array}{l}\text {-Shorter lead time } \\
-12 \% \text { revenues growth }\end{array}$ & $\begin{array}{l}\text {-Availability of skilled } \\
\text { people }\end{array}$ \\
\hline $\begin{array}{l}\text { AutoCo } \\
\text { Automotive } \\
\text { components } \\
\text { (D) }\end{array}$ & $\begin{array}{l}\text {-Effective TCO higher than } \\
\text { expected } \\
\text {-Poor product quality }\end{array}$ & $\begin{array}{l}\text {-Profits (small ones) } \\
\text {-Higher product quality }\end{array}$ & $\begin{array}{l}\text {-Investments in CNC } \\
\text { machine } \\
\text {-Availability of skilled } \\
\text { people }\end{array}$ \\
\hline $\begin{array}{c}\text { RubberCo } \\
\text { Automotive (E) }\end{array}$ & $\begin{array}{l}\text {-Delivery time } 4-6 \text { weeks ( } 12 \text { if } \\
\text { the product did not pass the } \\
\text { quality check in the UK) } \\
\text {-Effective TCO higher than } \\
\text { expected }\end{array}$ & $\begin{array}{l}\text {-Delivery time } 24 \text { hours } \\
\text {-Strategic shift (repositioning on } \\
\text { high end segments) }\end{array}$ & $\begin{array}{l}\text {-Availability of skilled } \\
\text { people }\end{array}$ \\
\hline $\begin{array}{l}\text { LaundryCo } \\
\text { Laundry } \\
\text { products (F) }\end{array}$ & $\begin{array}{l}\text {-Lead time 3-4 months } \\
\text {-Scarcity of cash flow (payment in } \\
\text { advance) } \\
\text {-Poor product quality } \\
\text {-Product } \mathrm{CO} 2 \text { emission } \\
\text { inconsistent with eco-friendly } \\
\text { product positioning }\end{array}$ & $\begin{array}{l}\text {-Payment after receiving products } \\
\text {-Cooperation with local partners } \\
\text { for new product development } \\
\text {-Increase in total cost }\end{array}$ & $\begin{array}{l}\text {-Availability of skilled } \\
\text { people }\end{array}$ \\
\hline $\begin{array}{l}\text { ComputerCo } \\
\text { Computer } \\
\text { systems (G) }\end{array}$ & $\begin{array}{l}\text {-Effective lead time } 10 \text { weeks (the } \\
\text { agreed time was six weeks) } \\
\text {-Payment in advance ( } 12 \text { weeks) }\end{array}$ & $\begin{array}{l}\text {-Lead time three weeks } \\
\text {-Product re-design in collaboration } \\
\text { with suppliers for component } \\
\text { number and assembling times } \\
\text { reduction } \\
\text {-Increased sales volumes } \\
\text {-Reduced inventory levels }\end{array}$ & $\begin{array}{l}\text {-Availability of skilled } \\
\text { people }\end{array}$ \\
\hline $\begin{array}{l}\text { GarmentCo } \\
\text { Cashmere } \\
\text { made garment } \\
\text { (H) }\end{array}$ & $\begin{array}{l}\text {-Lead time ( } 12 \text { weeks) } \\
\text {-Geographic distance between } \\
\text { design and manufacturing } \\
\text {-Made in-effect } \\
\text {-Poor product quality }\end{array}$ & $\begin{array}{l}\text {-Shorter lead time } \\
\text {-New product development in } \\
\text { collaboration with suppliers } \\
\text {-Offshoring project ended }\end{array}$ & $\begin{array}{l}\text {-Availability of skilled } \\
\text { people }\end{array}$ \\
\hline
\end{tabular}




\section{Discussion}

The comparative analysis of sampled case studies has enabled us to characterise the backshoring phenomenon in the UK to provide useful insights for companies aiming to implement back-shoring strategies and embark on a new ILD after Brexit. In doing so, the findings are discussed in light of the $5 \mathrm{~W} \& 1 \mathrm{H}$ approach and five propositions are developed to be further investigated in future research.

The results considering the offshoring destination ("Where" issue) show that seven out of eight sampled companies targeted China and Far East Asia which appears to be consistent with offshoring literature in European countries (Kinkel, \& Maloca, 2009; Ellram, et al. 2013). Meanwhile, with respect to the 'Why' issue (Figure 2), all respondents acknowledged having offshored mainly to reduce production costs. In this respect Haleem et al. (2018) state that 'although cost is still an important factor, today offshoring decisions are driven by a variety of motives, including performance (e.g. low material, labor and other variable costs; productivity; flexibility and quality) and functional benefits (e.g. access to skills, knowledge or technology; learning opportunities; market access; proximity to suppliers or competitors)'. However, in our study only a few companies also cited the lack of capacity and qualified suppliers at the home country or access to labour, resources and know-how in the host country as motivations behind offshoring. With respect to the "external/internal environment" dimension of the Fratocchi et al. (2016) framework, all companies offshored due to "external environment" motivations (Di Mauro et al. 2018). These findings are in line with the extant literature on offshoring motivations (Roza, et al. 2011; Kinkel, \& Maloca, 2009; Ellram, et al. 2013; Johansson et al. 2018).

More importantly looking at the back-shoring motivations, it appears that a wider set of factors influenced this particular ILD. All the firms in this study indicated the reduced responsiveness to customer demand and production and increased delivery time, regardless of the type of business, to be the key motivations behind the back-shoring decision. These drivers (which all belong to the "internal environment" of back-shoring companies) are consistent with previous study by Moradlou et al. (2017a) referring to UK companies back-shoring from India. It is important to note that the above motivations stem from changing demand and delivery expectations at the home country rather than solely being due to previous miscalculation. Study by Moradlou and Tate (2018) and Fratocchi (2018) also show the role of new generation of technologies, additive manufacturing, in back-shoring decision. Our result shows that the 
companies did not implement back-shoring decisions only as a correction of a previous managerial mistake (Kinkel and Maloca, 2009; Dachs et al., 2019) but also as a consequence of a change in the external environment (Martinez-Mora and Merino, 2014). More specifically, it was only in the AutoCo case study that the interviewee explicitly recognised that the effective Total Cost of Ownership at the host country, due to offshoring hidden costs (Larsen et al. 2013), was higher than originally calculated. The above discussion leads to the following proposition:

Proposition 1: Back-shoring can stem from both misjudgements of previous offshoring decisions as well as changes in the demand pattern at the home country.

The second and third drivers behind back-shoring decisions were found to be the reduced operational flexibility (internal environment) and poor product quality (external environment), respectively, due to a substandard manufacturing culture in the host country and lack of direct monitoring. These findings are consistent with those found in other European countries (Fratocchi et al. 2016; Heikkilä et al. 2018b; Engström et al. 2018a; Wiesmann et al. 2017). It is worth noting that the top four back-shoring drivers are related to the '"customer perceived value" category while those related to the "cost-efficiency goal" are insignificant and not shared across all cases, especially when compared with the previous offshoring decision. In other terms, while the initial ILD was mainly related to cost reduction, back-shoring was initiated mainly by differentiation strategies. This finding is consistent with previous evidence collected by Di Mauro et al. (2018) when investigating Italian relocation initiatives. Therefore, our results suggest that this proposition holds for the UK context:

Proposition 2: While the predominant motivation for UK offshoring is mainly cost-oriented, a strategic shift aimed at increasing the value perceived by the customer has a pivotal role in the back-shoring decision.

While addressing the 'When' aspect of our framework (offshoring duration), it can be noted that all sampled companies back-shored after, at most, five years. According to Kinkel and Maloca (2009) changes in manufacturing location decisions are mainly attributed to the correction of a previous managerial decision. Although this is evident in AutoCo who backshored after two years, the analysis shows that the majority of the interviewees back-shored manufacturing activities due to strategic shift (excluding two trial cases). For instance, this was evident at RubberCo, when the Operating Director decided to back-shore after shifting the focus from the automotive business to the oil and gas markets. This evidence is also consistent 
with the findings by Di Mauro et al. (2018) and Baraldi et al., (2018) and further supports Proposition 2.

While the first four drivers are common to all investigated companies, the secondary motivations are more specific to the firm's industry, confirming the importance of studying different sectors. For instance, the 'made in effect' was found as a secondary back-shoring driver in companies related to the fashion industry (ShoeCo and GarmentCo). This is consistent with previous findings, which indicates that Made in the UK story and heritage is a supporting factor for the back-shoring decision (Ashby, 2016; Robinson and Hsieh, 2016). In this respect, it is worth noting that the relevance of the made in effect in the fashion industry was also pointed out in other home country analysis (Di Mauro et al, 2018; Baraldi et al, 2018). At the same time, the difficulty in accessing highly productive skilled workers and differences in manufacturing culture at the host country were cited in automotive components (AutoCo and RubberCo) and furniture industries (SofaCo and BedCo). These findings are in line with a study undertaken by Bailey and De Propris, (2014a, 2014b) with respect to the automotive industry. Therefore, it can be concluded that the other, secondary, motivations behind the backshoring phenomenon can be more industry-specific and are dependent on the nature of production (e.g. type of products, production volume, and time sensitivity of production processes). The above discussion leads to the following proposition:

Proposition 3: While responsiveness is a significant driver for back-shoring, irrespective of the companies' industry sector, other drivers are more industry-specific (e.g., consumable vs durable products).

With respect to the governance mode after back-shoring (How), it was observed that both outsourcing and in-sourcing strategies were adopted. The analysis indicates that it is more feasible for larger companies to repatriate manufacturing activities to an in-house facility. This is partially due to availability of the required capital for further investment on production facilities. In-sourcing may be considered as a further vertical integration, where foreign suppliers are replaced by in-house operations which can result in more control over manufacturing activities and ensure better quality (Matsubayashi, 2007). Meanwhile, lack of finance in SMEs is the main constraint for such a strategy (Beck and Demirguc-Kunt, 2006). Hence, SMEs are more likely to back-shore their manufacturing activities by selecting local suppliers while continuing to outsource their operations. By using local partners, SMEs can reduce their foreign suppliers and manage to be responsive towards customer demand 
(Moradlou et al., 2017a; Moradlou and Tate 2018). High inventory and MOQ are also among the listed reasons (cost efficiency based) for back-shoring by a number of companies.

When considering offshoring and back-shoring outcomes, it is evident that they often refer to operation-based issues (e.g., lead time, product quality) and financial issues (e.g., total cost of ownership, working capital) (Stentoft et al., 2018). However, two additional performance related outcomes emerged as pertinent when analysing LaundryCo, RubberCo and ComputerCo. It should be noted that LaundryCo was the only case among the samples that predominantly focused on sustainability in their production. This was due to brand positioning and company image which was associated with eco-friendly product designs. Back-shoring decision in turn allowed LaundryCo to source its product closer to the assembly process at home, saving on transportation and total emission levels (carbon footprint). The relationship between back-shoring and environmental sustainability has been recently investigated as an unexplored angle to this type of ILD (Orzes and Sarkis 2019; Fratocchi \& Di Stefano, 2019; Martinez-Mora and Merino, 2020). Moreover, in all three aforementioned cases, improvement in product design and encouragement for innovation was captured. This manifested itself by the further development in collaboration with suppliers at the home country to develop new products and technologies (Moradlou et al., 2020b). Proximity to the suppliers and sharing the same language and time zone were viewed as facilitating factors for enhancing the collaboration. The above discussion leads to the following proposition:

Proposition 4: Back-shoring decisions enable companies to obtain performance outcomes also related to sustainability and innovation issues.

In terms of the barriers for back-shoring, all of our participants declared scarcity of skilled human resource to be the main obstacle during implementation of back-shoring strategies. The existing literature does not provide a complete overview of potential failures/barriers concerning the repatriation of production to the home country (Nujen et al., 2018, Wiesmann et al., 2017). In a similar vein, Nujen et al. (2019) argue that companies should assess the knowledge and experience required for their operations prior to the back-shoring decision and, subsequently, broaden their knowledge base to develop distinctive manufacturing capabilities or, alternatively, find a local/regional supplier with a readily-accessible infrastructure and workforce to support operations. However, research shows that UK companies have faced a shortage of skilled workforce for more than half a decade since backshoring gained momentum in the UK. For instance, Bailey and De Propris, (2014a) point out 
'over the last two decades, offshoring has hollowed out many previously nationally, and often regionally, based manufacturing sectors' $(2014$, pp. 14). This has resulted in a dramatic reduction in availability of the workforce depleted by extensive offshoring which explains the reason that the two offshoring trial cases (GramentCo and RubberCo) also cited skills shortage as a barrier. The scarcity of skilled people has been more recently referred to as a relevant backshoring barrier by Engström et al. (2018a, 2018b). This becomes further alarming as we approach the Brexit transition period which is believed to worsen the workforce availability in the UK (Bailey et al. 2020). The above discussion leads to the following proposition:

Proposition 5: Skill shortage is the main barrier for the implementation of back-shoring strategies in the UK and requires companies' attention prior to its repatriation.

\section{Conclusion and future research area}

\subsection{Theoretical and practical contribution}

This study offers important contributions to the back-shoring literature as it provides a distinctive analysis on country-specific back-shoring decisions. By focusing on the context of the UK as one of the EU's major economies, we respond to the research call by Wan et al. (2019). Whilst the analysis reveals that "cost efficiency factors" appear to be the main drivers for offshoring decisions in all the cases, conversely the evidence shows that back-shoring motivations tend to centre around factors which are classified as "customer perceived value". This paper has provided a unique insight by cross-comparing companies that operate in various sectors including automotive, furniture, computer, garment, laundry product and apparel. The findings indicate that, regardless of the nature of the industry, companies choose to repatriate their manufacturing activities in order to shorten their supply chain and be more responsive towards customer demand. This applies to both high value-added products as well as price sensitive products. The latter challenges an implicit assumption that companies predominantly back-shore high value-added activities. Responsiveness, as a common attribute among all the participants, highlights the importance of a back-shoring strategy to UK industries especially after Brexit, which is not merely a correction of previous offshoring failure, but more of a strategic decision to meet demand in the UK.

For practitioners, the case studies indicate the imperative to evaluate principles and understand the back-shoring strategy in the UK. The study elaborates on eight different backshoring experiences which can be translated into supply chain issues to better understand the relocation decisions after Brexit. The study presents and analyses companies' motivations, 
benefits and risks related to both manufacturing offshoring and back-shoring, which have managerial implications and can be used as a set of guidelines for future decision-making. Due to the diversity of the selected cases, cross-case analysis provided a clear image of commonalities and differences between various industries. Difficulties in accessing a trained workforce remains the main constraint of back-shoring which requires the re-introduction of materials, manufacturing and skills that had disappeared through the widespread offshoring experienced in the UK. Doing so will enable companies in the UK to access the required talent once the Brexit transition period is over.

\subsection{Future Research Area}

In addition to our five propositions, a number of findings emerged when investigating the 'What' and 'When' aspect. In this respect, ShoeCo and LaundryCo represent unique cases compared to the extant back-shoring literature as they were both "born offshored" under a manufacturing point of view, since their production activities were based overseas when they were established. Such unexplored scenarios can lead to a new research question as follows: Can investigation of "manufacturing born offshored companies" be considered a different unit of analysis for the researchers? If yes, are the decision making and implementation processes different from those proposed studies in the extant literature (Boffelli et al. 2018; 2020)? Study done by Boffelli and Johansson (2020) provides a decision making framework to capture all dimensions of decision making considering the internal/external environment for both offshoring and back-shoring decisions. Hence how does born offshored companies fit into the already existing frameworks in back-shoring literature? In a similar vein Heikkila et al. (2018b) state that 'back-shoring does NOT necessarily mean that companies return the same production that was initially moved abroad. Offshoring and back-sourcing refer to transferring production permanently from one geographic location to another location'. In other words, the backshoring phenomenon would be referred to as a production activity rather than to a specific product (lines).

Further insights emerged when analysing the two companies who implemented trial projects to assess the feasibility of offshoring their production activities (RubberCo and GarmentCo). Whilst Boffelli et al. $(2018 ; 2020)$ have studied the trial and error approach to explain how SMEs take back-shoring decisions, the role of trial projects has not been investigated in the previous offshoring literature. Our findings indicate that both trial projects faced a number of problems, similar to other cases in this study, during the implementation 
phase which resulted in a negative evaluation of the offshoring strategy. It is worth noting that prior to the trial projects, both companies were producing goods in-house, indicating an extent of capital investment tied up in production. Further research can be undertaken to explore the relationship between in-house production prior to back-shoring and the tendency to conduct offshoring trial projects to assess the offshoring decision. In other words, is a company who has in-house productions before offshoring more likely to run offshoring trials than a company who is already working with domestic suppliers? This require an investigation of offshoring trial projects and the governance mode prior to the decision making.

Despite careful design of the research model, there are several limitations in this study. It should be noted that this research adopts a multiple case study approach and conducts qualitative analysis on limited interview data. As a result, the findings can lack generalisability to a larger population within UK industries. For future research opportunities, the results can be further elaborated upon by conducting more case studies in the UK together with survey studies to validate the outcome of this research. We also call on future researchers to test the propositions developed in this paper. Additionally, companies in other countries can show different behaviours when it comes to manufacturing location decisions. This can be evident in terms of the choice of the offshoring destination as well as the type of back-shoring. Hence, further research is recommended to investigate country-specific factors affecting the backshoring decision. 


\section{References}

Arlbjørn, J. S. and Mikkelsen, O. S. (2014), "Backshoring manufacturing: Notes on an important but under-researched theme", Journal of Purchasing \& Supply Management, Vol. 20, No. 1, pp. 60-62.

Ashby, A. (2016). From global to local: reshoring for sustainability. Operations Management Research, 9(3-4), 75-88.

Bailey, D. and De Propris, L. (2014a), 'Manufacturing reshoring and its limits: the UK automotive case', Cambridge Journal of Regions, Economy and Society, Vol. 7 No. 3, pp. 379395

Bailey, D., \& De Propris, L. (2014b). Reshoring: Opportunities and Limits for Manufacturing in the UK-the case of the Auto Sector. Revue d'économie industrielle, (145), 45-61.

Bailey, D., Ruyter, A., Fowler, N. \& Mair, J. (2020). Carmageddon? Brexit \& Beyond for UK Auto. Bite-Sized Books Ltd

Bailey, D., Corradini, C., De Propris, L., (2018), "Home-sourcing' and closer value chains in mature economies: the case of Spanish manufacturing", Cambridge Journal of Economics, Vol. 42, Issue 6, pp. 1567-1584

Bals, L., Kirchoff, J. F., \& Foerstl, K. (2016). Exploring the reshoring and insourcing decision-making process: toward an agenda for future research. Operations Management Research, 9(3-4), 102-116.

Baraldi, E., Ciabuschi, F., Lindahl, O., \& Fratocchi, L. (2018). A network perspective on the reshoring process: The relevance of the home- and the host-country contexts. Industrial Marketing Management, 70, 156-166. https://doi.org/10.1016/j.indmarman.2017.08.016

Barbieri, P., Boffelli, A., Elia, S., Fratocchi, L., Kalchschmidt, M., \& Samson, D. (2020). What can we learn about reshoring after Covid-19?. Operations Management Research, 1-6.

Barbieri, P., Ciabuschi, F., Fratocchi, L., \& Vignoli, M. (2018). What do we know about manufacturing reshoring? Journal of Global Operations and Strategic Sourcing, 11(1), 79-122.

Barbieri, P., Elia, S., Fratocchi, L., \& Golini, R. (2019). Relocation of second degree: Moving towards a new place or returning home? Journal of Purchasing and Supply Management, 1-14. https://doi.org/10.1016/j.pursup.2018.12.003

Beck, T., \& Demirguc-Kunt, A. (2006). Small and medium-size enterprises: Access to finance as a growth constraint. Journal of Banking \& finance, 30(11), 2931-2943.

Benstead, A.V., Stevenson, M. \& Hendry, L.C. 2017. "Why do firms reshore? A contingency-based conceptual approach." Operations Management Research, 10, 3-4, 85-103.

Bettiol, M., Burlina, C., Chiarvesio, M. \& Di Maria, E. (2017). From delocalisation to backshoring? Evidence from Italian industrial districts. Investigaciones Regionales, 39, 137154.

Boffelli, A., Golini, R., Orzes, G., \& Dotti, S. (2018). "How to reshore": Some evidence from the apparel industry. IEEE Engineering Management Review. https://doi.org/10.1109/EMR.2018.2886183 
Boffelli, A., Golini, R., Orzes, G., \& Dotti, S. (2020), Open the box: A behavioural perspective on the reshoring decision-making and implementation process, Journal of Purchasing and Supply Management, https://doi.org/10.10161/j.pursup.2020.100623

Boffelli, A., \& Johansson, M., (2020), What do we want to know about reshoring? Towards a comprehensive framework based on a meta-synthesis, Operations Management Research, https://doi.org/0.1007/s12063-020-00155-y

Brennan, L., Ferdows, K., Godsell, J., Golini, R., Keegan, R., Kinkel, S., ... \& Taylor, M. (2015). Manufacturing in the world: where next? International Journal of Operations \& Production Management, 35(9), 1253-1274.

Dachs, D., Kinkel, S., Jäger, A., Palčič, I. (2019a). Backshoring of production activities in European manufacturing. Journal of Purchasing and Supply Management. doi.org/10.1016/j.pursup.2019.02.003

Dachs, B., Kinkel, S., Jäger, A., (2019b). Bringing it all back home? Backshoring of manufacturing activities and the adoption of Industry 4.0 technologies. Journal of World Business, 54(6), 101017.

De Backer, K., Menon, C., Desnoyers-James, I., \& Moussiegt, L. (2016). Reshoring: Myth or Reality? OECD Science, Technology and Industry Policy Papers, No. 27 OECD Publishing, Paris, France.

De Propris, L \& Bailey, D 2017, 'Brexit and the UK automotive industry' National Institute Economic Review, vol.242, no. 1.

Di Mauro, C., Fratocchi, L., Orzes, G., \& Sartor, M. (2018). Offshoring and backshoring: A multiple case study analysis. Journal of Purchasing and Supply Management, 24(2), 108134.

Eisenhardt, K. M. (1989). Building theories from case study research. Academy of management review, 14(4), 532-550.

Ellram, L. M. (1996). The use of the case study method in logistics research. Journal of business logistics, 17(2), 93.

Ellram, L.M. (2013), "Offshoring, reshoring and the manufacturing location decision", Journal of Supply Chain Management, Vol. 49 No. 2, pp. 3-5.

Ellram, L.M., Tate, W.L. and Petersen, K.J. (2013), “Offshoring and reshoring: an update on the manufacturing location decision", Journal of Supply Chain Management, Vol. 49 No. 2, pp. 14-22.

Engström, G., Sollander, K., Hilletofth, P., \& Eriksson, D. (2018a). Reshoring drivers and barriers in the Swedish manufacturing industry. Journal of Global Operations and Strategic Sourcing, 11(2), 174-201.

Engström, G., Hilletofth, P., Eriksson, D., \& Sollander, K. (2018b). Drivers and barriers of reshoring in the Swedish manufacturing industry. World Review of Intermodal Transportation Research, 7(3), 195-220.

Fel, F., \& Griette, E. (2017). Near-reshoring your supplies from China: a good deal for financial motives too. Strategic Direction, 33(2), 24-26. 
Financial Times, (2020). UK looks to wean itself off Chinese imports. [Online] https://www.ft.com/content/dc22913c-4abd-4258-89fb-e45a4342e2a6, Retrieved Sep 25, 2020

Fine, C. (2013), "Intelli-sourcing to replace offshoring as supply chain transparency increases", Journal of Supply Chain Management, Vol. 49 No. 2, pp. 6-7.

Fjellstrom D, Fang T, Chimenson D (2019) Explaining reshoring in the context of Asian competitiveness: evidence from a Swedish firm. Journal of Asian Business Studies, 13(2):277293.

Fratocchi, L., Di Mauro, C., Barbieri, P., Nassimbeni, G. and Zanoni, A. (2014), "When manufacturing moves back: concepts and questions", Journal of Purchasing and Supply Management, Vol. 20 No. 1, pp. 54-59.

Fratocchi, L., Ancarani, A., Barbieri, P., Di Mauro, C., Nassimbeni, G., Sartor, M., Vignoli, M., \& Zanoni, A. (2016). Motivations of manufacturing reshoring: an interpretative framework. International Journal of Physical Distribution \& Logistics Management, 46(2), 98127.

Fratocchi, L., (2018). Additive manufacturing technologies as a reshoring enabler: a why, where and how approach. World Review of Intermodal Transportation Research, Vol. 7, No. 3, pp. 264-293

Fratocchi, L., Ancarani, A., Barbieri, P., Di Mauro, C., Troiano, A., Vignoli, M., Zanoni, A., (2015). Manufacturing Back- and Near-reshoring: A comparison of European and North American Companies, in Stentoft, J., Paulrai, A, Vastag, G., Research in the Decision Sciences for Global Supply Chain Network Innovations. Best papers from the 2014 Annual Conference, Pearson, pp. 107-128.

Fratocchi, L., Di Stefano, C., (2019). Does sustainability matter for reshoring strategies? A literature review. Journal of Global Operations and Strategic Sourcing, 12, pp. 449-476

Gray, J. V., Skowronski, K. and Rungtusanatham, M. J. (2013), "The reshoring phenomenon: what supply chain academics ought to know and should do", Journal of Supply Chain Management, Vol. 49 No. 2, pp. 27-33.

Grandinetti R, Tabacco R (2015) A return to spatial proximity: combining global suppliers with local subcontractors. International Journal of Global Small Business, 7(2):139161.

Groom, B. and Parker, G. (2014), "David Cameron tries to push reshoring with new advisory service", The Financial Times, January 24, available at: https://www.ft.com/content/909e46fa-8453-11e3-9710-00144feab7de, Retrieved Oct 4, 2018

Gylling M, Heikkilä J, Jussila K, Saarinen M (2015) Making decisions on offshore outsourcing and backshoring: A case study in the bicycle industry. International Journal of Production Economics, 162:92-100.

Haleem, F., Farooq, S., Wæhrens, B. V., \& Boer, H. (2018). Offshoring experience and performance: the role of realized drivers and risk management. Supply Chain Management: An International Journal. Vol. 23 No. 6, pp. 531-544. https://doi.org/10.1108/SCM-02-2018-0074

Heikkilä, J., Martinsuo, M., \& Nenonen, S. (2018a). Backshoring of production in the context of a small and open Nordic economy. Journal of Manufacturing Technology Management, 29(4), 658-675. 
Heikkilä, J., Nenonen, S., Olhager, J., \& Stentoft, J. (2018b). Manufacturing relocation abroad and back: Empirical evidence from the Nordic countries. World Review of Intermodal Transportation Research, 7(3), 221-240.

Huq, F., Pawar, K. S., \& Rogers, H. (2016). Supply chain configuration conundrum: how does the pharmaceutical industry mitigate disturbance factors?. Production Planning \& Control, 27(14), 1206-1220.

Johansson, M., \& Olhager, J. (2018a). Comparing offshoring and backshoring: The role of manufacturing site location factors and their impact on post-relocation performance. International Journal of Production Economics 205, 37-46.

Johansson, M., \& Olhager, J. (2018b). Manufacturing relocation through offshoring and backshoring: The case of Sweden. Journal of Manufacturing Technology Management, 29(4), 637-657.

Johansson, M., Olhager, J., Heikkilä, J., \& Stentoft, J. (2019). Offshoring versus backshoring: Empirically derived bundles of relocation drivers, and their relationship with benefits. Journal of Purchasing \& Supply Management. doi: 10.1016/j.pursup.2018.07.003

Joubioux, C., and Vanpoucke, E. (2016). Towards right-shoring: a framework for offand re-shoring decision making. Operations Management Research, 9(3-4), 117-132.

Kinkel, S. (2012), “Trends in production relocation and backshoring activities: changing patterns in the course of the global economic crisis", International Journal of Operations \& Production Management, Vol. 32 No. 6, pp. 696-720.

Kinkel, S. (2014), "Future and impact of backshoring-some conclusions from 15 years of research on German practices", Journal of Purchasing and Supply Management, Vol. 20 No. 1, pp. 63-65.

Kinkel S, Lay G, Maloca S (2007) Development, motives and employment effects of manufacturing offshoring of German SMEs. International Journal of Entrepreneurship and Small Business, 4(3):256-276.

Kinkel, S. and Maloca, S. (2009), "Drivers and antecedents of manufacturing offshoring and backshoring-a German perspective", Journal of Purchasing and Supply Management, Vol. 15 No. 3, pp. 154-165.

Lampón JF, González-Benito J (2019) Backshoring and improved key manufacturing resources in firms' home location. International Journal of Production Research, https://doi.org/10.1080/00207543.2019.1676479

Larsen, M., Manning, S., \& Pedersen, T. (2013). Uncovering the hidden costs of offshoring: The interplay of complexity, organizational design, and experience. Strategic Management Journal, 34(5), 533-552

Logistics Manager, (2020). Campaign group calls for reshoring of UK manufacturing supply chains. [Online] https://www.logisticsmanager.com/campaign-group-calls-forreshoring-of-uk-manufacturing-supply-chains/, Retrieved Sep 25, 2020

Manning, S., 2014, Mitigate, tolerate or relocate? Offshoring challenges, strategic imperatives and resource constraints, Journal of World Business, 49 (4), 522-535. 
Martınez-Mora, C., and Merino, F., (2020) Consequences of sustainable innovations on the reshoring drivers' framework, Journal of Manufacturing Technology Management DOI 10.1108/JMTM-12-2019-0426

Martínez-Mora, C., \& Merino, F. (2014). Offshoring in the Spanish footwear industry: A return journey? Journal of Purchasing and Supply Management, 20(4), 225-237.

Matsubayashi, N. (2007). Price and quality competition: the effect of differentiation and vertical integration. European Journal of Operational Research, 180(2), 907-921.

Moradlou, H. and Backhouse, C.J. (2016a) 'A review of manufacturing reshoring in the context of customer-focused postponement strategies', Proceedings of the Institution of Mechanical Engineers, Part B: Journal of Engineering Manufacture, Vol. 230, No. 9, pp.15611571 .

Moradlou, H. and Backhouse, C.J. (2016b) 'An Investigation into reshoring decision: case study approach', Advances in Transdisciplinary Engineering, Vol. 3, pp. 439-444.

Moradlou, H., Backhouse, C.J. and Ranganathan, R. (2017a) 'Responsiveness, the primary reasons behind reshoring manufacturing activities to the U.K.: an Indian industry perspectives', International Journal of Physical Distribution and Logistics Management, Vol. 47, Nos. 2/3, pp.222-236.

Moradlou, H., Reefke. H, \& Skipworth, H. (2020a). 'Manufacturing heading out, distribution moving in - the effects of Brexit' Carmageddon: Brexit \& Beyond for UK Auto Bite-Sized Brexit Books, 95

Moradlou, H., Roscoe, S., \& Ghadge, A. (2020b). Buyer-supplier collaboration during emerging technology development. Production Planning \& Control, 1-16. DOI: $10.1080 / 09537287.2020 .1810759$

Moradlou, H., Sawhney, R., Backhouse, C.J. and Mountney, S. (2017b) 'Investigation on additive Manufacturing as an enabler for reshoring manufacturing activities', 24th EurOMA Conference, July,

Moradlou, H. and Tate, W. (2018) 'Reshoring and additive manufacturing', World Review of Intermodal Transportation Research, Vol. 7, No. 3, pp.241-263.

Moretto A, Patrucco AS, Harland CM (2020) The dynamics of reshoring decisions and the role of purchasing. International Journal of Production Research, 58(19):5929-5944.

Mudambi, R., 2008, Location, control and innovation in knowledge-intensive industries, Journal of Economic Geography, 8 (5), 699-725.

Mukherjee, D. (2018). Hidden costs of offshore outsourcing: an analysis of offshoring decisions. Journal of Industry, Competition and Trade, 18(3), 303-318.

Nujen, B. B., Mwesiumo, D. E., Solli-Sæther, H., Slyngstad, A. B., \& Halse, L. L. (2019). Backshoring readiness. Journal of Global Operations and Strategic Sourcing. Vol. 12 No. 1, pp. 172-195. https://doi.org/10.1108/JGOSS-05-2018-0020

Nujen, B. B., Halse, L. L., Damm, R., \& Gammelsæter, H. (2018). Managing reversed (global) outsourcing-the role of knowledge, technology and time. Journal of Manufacturing Technology Management. Vol. 29 No. 4, pp. 676-698. https://doi.org/10.1108/JMTM-022017-0023 
Orzes, G., \& Sarkis, J. (2019). Reshoring and environmental sustainability: An unexplored relationship?. Resources, Conservation and Recycling, 141, 481-482.

Pal, R., Harper, S., \& Vellesalu, A. (2018). Competitive manufacturing for reshoring textile and clothing supply chains to high-cost environment: A Delphi study. The International Journal of Logistics Management. Vol. 29 No. 4, pp. 1147-1170. https://doi.org/10.1108/IJLM10-2017-0270 London.

Patton, M.Q., 2002. Qualitative Research \& Evaluation Methods. Sage Publications,

Patton, M. Q. (2014). Qualitative research \& evaluation methods: Integrating theory and practice. Sage publications.

Robinson P.K., Hsieh L., (2016) Reshoring: a strategic renewal of luxury clothing supply chains. Operation Management Research, 9(3-4):89-101.

Roscoe, S., Skipworth, H., Aktas, E., \& Habib, F. (2020). Managing supply chain uncertainty arising from geopolitical disruptions: evidence from the pharmaceutical industry and brexit. International Journal of Operations \& Production Management.

Roza, M., Van den Bosch, F. A., \& Volberda, H. W. (2011). Offshoring strategy: Motives, functions, locations, and governance modes of small, medium-sized and large firms. International Business Review, 20(3), 314-323.

Schmidt, A. S. T., Touray, E., \& Hansen, Z. N. L. (2017). A framework for international location decisions for manufacturing firms. Production Engineering, 11(6), 703-713.

Srai, J. S., \& Ané, C. (2016). Institutional and strategic operations perspectives on manufacturing reshoring. International Journal of Production Research, 54(23), 7193-7211.

Stauss, B., \& Weinlich, B. (1997). Process-oriented measurement of service quality: applying the sequential incident technique. European Journal of Marketing, 31(1), 33-55.

Stentoft, J., Mikkelsen, O.S., Jensen, J.K. \& Rajkumar, C. (2018). Performance outcomes of offshoring, backshoring and staying at home manufacturing. International Journal of Production Economics, 199, 199-208

Stentoft J, Mikkelsen OS, Jensen JK (2016a) Flexicurity and relocation of manufacturing. Operation Management Research, 9(3-4):133-144.

Stentoft J, Mikkelsen OS, Jensen JK (2016b) Offshoring and backshoring manufacturing from a supply chain innovation perspective. Supply Chain Forum 17(4):190-204.

Stentoft, J., Olhager, J., Heikkilä, J., \& Thoms, L. (2016c). Manufacturing backshoring: a systematic literature review. Operations Management Research, 9(3-4), 53-61.

Tate, W., Ellram, L., Bals, L. and Hartmann, E. (2009), "Offshore outsourcing of services: an evolutionary perspective", International Journal of Production Economics, Vol. 120 No. 2, pp. 512-524.

Tate, W. (2014), "Offshoring and reshoring: US insights and research challenges", Journal of Purchasing and Supply Management, Vol. 20 No. 1, pp. 66-68.

The Economist, (2017). Brexit triggers a round of reshoring. [Online] https://www.economist.com/britain/2017/10/19/brexit-triggers-a-round-of-reshoring.

Retrieved Oct 10, 2018 
The Telegraph, (2020). Companies look to reshore after Covid decimates supply chains. [Online] https://www.telegraph.co.uk/business/2020/08/28/companies-look-reshore-coviddecimates-supply-chains/ Retrieved Sep 25, 2020

Theyel, G., Hofman, K., Gregory, M., (2018), "Understanding lcation decision making: Offshoring, Reshoring and Hybrid Approaches, Economic development quarterly, Vol. 4, 300312.

Tsimiklis, P., \& Makatsoris, C. (2019). Redistributing food manufacturing: models for the creation and operation of responsive and agile production networks. Production Planning \& Control, 30(7), 582-592.

UNCTAD, (2015). World Investment Report 2015, Reforming International Investment Governance. [Online] http://unctad.org/en/PublicationsLibrary/wir2015_en. pdf, Retrieved Oct 10, 2018

Waehrens, B. V., Slepniov, D., \& Johansen, J. (2015). Offshoring practices of Danish and Swedish SMEs: effects on operations configuration. Production Planning \& Control, 26(9), 693-705.

Wan, L., Orzes, G., Sartor, M., \& Nassimbeni, G. (2019). Reshoring: Does home country matter?. Journal of Purchasing and Supply Management, 25(4), 100551.

Wiesmann, B., Snoei, J. R., Hilletofth, P., \& Eriksson, D. (2017). Drivers and barriers to reshoring: a literature review on offshoring in reverse. European Business Review, 29(1), 1542.

Yin (2014) Case study research: Design and methods (applied social research methods). London and Singapore: Sage 
Appendix 1 
Table 6, Systematic Literature Review

\begin{tabular}{|c|c|c|c|c|c|c|c|c|c|c|c|c|}
\hline Authors & $\begin{array}{l}\text { Journal/Book } \\
\text { chapter }\end{array}$ & Year & $\begin{array}{l}\text { Research } \\
\text { methodology }\end{array}$ & $\begin{array}{l}\text { Investigated } \\
\text { Home country }\end{array}$ & Industry & Drivers & $\begin{array}{l}\text { Enabling } \\
\text { factors }\end{array}$ & Barriers & Outcomes & $\begin{array}{l}\text { Governance } \\
\text { mode }\end{array}$ & $\begin{array}{l}\text { Degree of } \\
\text { reshoring }\end{array}$ & Ownership \\
\hline $\begin{array}{l}\text { Arlbørn, J.S., } \\
\text { Mikkelsen, O.S. }\end{array}$ & $\begin{array}{l}\text { Journal of } \\
\text { Purchasing and } \\
\text { Supply } \\
\text { Management }\end{array}$ & 2014 & Survey & Denmark & Several & $x$ & $x$ & & & $x$ & & \\
\hline $\begin{array}{l}\text { Bailey, D., } \\
\text { Corradini, C., De } \\
\text { Propris, L. }\end{array}$ & $\begin{array}{l}\text { Cambridge Journal } \\
\text { of Economics }\end{array}$ & 2018 & Survey & Spain & Several & & $x$ & & & & & \\
\hline $\begin{array}{l}\text { Baraldi, } \\
\text { E., Ciabuschi, } \\
\text { F., Lindahl, } \\
\text { O., Fratocchi, L. } \\
2018\end{array}$ & $\begin{array}{l}\text { Industrial } \\
\text { Marketing } \\
\text { Management }\end{array}$ & 2018 & 1 Case study & Italy & Footwear & $x$ & $x$ & & $x$ & & $x$ & \\
\hline $\begin{array}{l}\text { Bettiol, } \\
\text { M., Burlina, } \\
\text { C., Chiarvesio, } \\
\text { M., Di Maria, E. }\end{array}$ & $\begin{array}{l}\text { Investigaciones } \\
\text { Regionales }\end{array}$ & 2017 & Survey & Italy & Several & $x$ & & & & & & \\
\hline $\begin{array}{l}\text { Boffelli, A., } \\
\text { Golini, R., Orzes, } \\
\text { G., Dotti, S. }\end{array}$ & $\begin{array}{l}\text { IEEE Engineering } \\
\text { Management } \\
\text { Review }\end{array}$ & 2018 & Case studies & Italy & Fashion & $x$ & $x$ & $x$ & & & & \\
\hline $\begin{array}{l}\text { Dachs, B., Kinkel, } \\
\text { S., Jäger, A. }\end{array}$ & $\begin{array}{l}\text { Journal of World } \\
\text { Business }\end{array}$ & 2019 & Survey & $\begin{array}{l}\text { Austria, } \\
\text { Germany, } \\
\text { Switzerland }\end{array}$ & Several & $x$ & $x$ & & & & & \\
\hline $\begin{array}{l}\text { Dachs, B., Kinkel, } \\
\text { S., Jäger, A., } \\
\text { Palčič, I. }\end{array}$ & $\begin{array}{l}\text { Journal of } \\
\text { Purchasing and } \\
\text { Supply } \\
\text { Management }\end{array}$ & 2019 & Survey & $\begin{array}{l}\text { Aaustria, } \\
\text { Croatia, } \\
\text { Germany, } \\
\text { Netherlands, } \\
\text { Serbia, } \\
\text { Slovenia, Spain, } \\
\text { Switwerladn, }\end{array}$ & Several & $x$ & & & & & & \\
\hline
\end{tabular}




\begin{tabular}{|c|c|c|c|c|c|c|c|c|c|c|c|c|}
\hline $\begin{array}{l}\text { Di Mauro, } \\
\text { C., Fratocchi, } \\
\text { L., Orzes, } \\
\text { G., Sartor, M. }\end{array}$ & $\begin{array}{l}\text { Journal of } \\
\text { Purchasing and } \\
\text { Supply } \\
\text { Management }\end{array}$ & 2018 & Case studies & Italy & $\begin{array}{l}\text { Textile, } \\
\text { Clothing, } \\
\text { Leather and } \\
\text { Footwear }\end{array}$ & $x$ & & & $x$ & $x$ & $x$ & \\
\hline $\begin{array}{l}\text { Engström, G., } \\
\text { Hilletofth, P., } \\
\text { Eriksson, D., } \\
\text { Sollander, K., } \\
2018\end{array}$ & $\begin{array}{l}\text { World Review of } \\
\text { Intermodal } \\
\text { transportation } \\
\text { research }\end{array}$ & 2018 & Case studies & Sweden & Several & $x$ & & $x$ & & & & \\
\hline $\begin{array}{l}\text { Engström, G., } \\
\text { Sollander, K., } \\
\text { Hilletofth, P., } \\
\text { Eriksson, D. } 2018\end{array}$ & $\begin{array}{l}\text { Journal of Global } \\
\text { Operations and } \\
\text { Strategic Sourcing }\end{array}$ & 2018 & Case studies & Sweden & Several & $x$ & & $x$ & & $x$ & & $x$ \\
\hline Fel, F., Griette, E. & Strategic Direction & 2017 & Survey & France & Several & $x$ & & & & & & \\
\hline $\begin{array}{l}\text { Fjellstrom, D., } \\
\text { Fang, T., } \\
\text { Chimenson, D. }\end{array}$ & $\begin{array}{l}\text { Journal of Asia } \\
\text { Business Studies }\end{array}$ & 2019 & & & & & & & & & & \\
\hline $\begin{array}{l}\text { Grandinetti, R., } \\
\text { Tabacco, R. }\end{array}$ & $\begin{array}{l}\text { International } \\
\text { Journal of } \\
\text { Globalisation and } \\
\text { Small Business }\end{array}$ & 2015 & 1 Case study & Italy & $\begin{array}{l}\text { Public } \\
\text { information } \\
\text { display } \\
\text { systems }\end{array}$ & $x$ & $x$ & & $x$ & & & \\
\hline $\begin{array}{l}\text { Gylling, M., } \\
\text { Heikkilä, J., } \\
\text { Jussilä, K., } \\
\text { Saarinen, M. }\end{array}$ & $\begin{array}{l}\text { International } \\
\text { Journal of } \\
\text { Production } \\
\text { Economics }\end{array}$ & 2015 & 1 Case study & Finland & Cycling & $x$ & & & $x$ & & $x$ & \\
\hline $\begin{array}{l}\text { Heikkilä, J., } \\
\text { Nenonen, S., } \\
\text { Olhager, J., } \\
\text { Stentoft, J }\end{array}$ & $\begin{array}{l}\text { World Review of } \\
\text { Intermodal } \\
\text { Transportation } \\
\text { Research }\end{array}$ & 2018 & Survey & $\begin{array}{l}\text { Denmark, } \\
\text { Finland \& } \\
\text { Sweden }\end{array}$ & Several & $x$ & & & $x$ & & & \\
\hline $\begin{array}{l}\text { Heikkilä, } \\
\text { J., Martinsuo, } \\
\text { M., Nenonen, S., } \\
2018\end{array}$ & $\begin{array}{l}\text { Journal of } \\
\text { Manufacturing } \\
\text { Technology } \\
\text { Management }\end{array}$ & 2018 & Survey & Finland & Several & $x$ & & & & & & $x$ \\
\hline $\begin{array}{l}\text { Johansson, M., } \\
\text { Olhager, J., } \\
\text { Heikkilä, J., } \\
\text { Stentoft, J. }\end{array}$ & $\begin{array}{l}\text { Journal of } \\
\text { Purchasing and } \\
\text { Supply } \\
\text { Management }\end{array}$ & 2019 & Survey & $\begin{array}{l}\text { Denmark, } \\
\text { Finland \& } \\
\text { Sweden }\end{array}$ & Several & $x$ & & & $x$ & & & \\
\hline
\end{tabular}




\begin{tabular}{|c|c|c|c|c|c|c|c|c|}
\hline $\begin{array}{l}\text { Johansson, } \\
\text { M., Olhager, J. }\end{array}$ & $\begin{array}{l}\text { Journal of } \\
\text { Manufacturing } \\
\text { Technology } \\
\text { Management }\end{array}$ & 2018 & Survey & Sweden & Several & $x$ & $x$ & $x$ \\
\hline $\begin{array}{l}\text { Johansson, } \\
\text { M., Olhager, J. }\end{array}$ & $\begin{array}{l}\text { International } \\
\text { Journal of } \\
\text { Production } \\
\text { Economics }\end{array}$ & 2018 & Survey & Sweden & Several & $x$ & $x$ & \\
\hline Kinkel, S. & $\begin{array}{l}\text { International } \\
\text { Journal of } \\
\text { Operations and } \\
\text { Production } \\
\text { Management }\end{array}$ & 2012 & Survey & Germany & Several & $x$ & & \\
\hline Kinkel, S. & $\begin{array}{l}\text { Journal of } \\
\text { Purchasing and } \\
\text { Supply } \\
\text { Management }\end{array}$ & 2014 & Survey & Germany & Several & $x$ & & $x$ \\
\hline $\begin{array}{l}\text { Kinkel, S., Lay, } \\
\text { G., Maloca, S. }\end{array}$ & $\begin{array}{l}\text { International } \\
\text { Journal of } \\
\text { Entrepreneurship } \\
\text { and Small business }\end{array}$ & 2007 & Survey & Germany & Several & $x$ & & \\
\hline $\begin{array}{l}\text { Kinkel, S., } \\
\text { Maloca, S. }\end{array}$ & $\begin{array}{l}\text { Journal of } \\
\text { Purchasing and } \\
\text { Supply } \\
\text { Management }\end{array}$ & 2009 & Survey & Germany & Several & $x$ & & \\
\hline $\begin{array}{l}\text { Lampon, JF \& } \\
\text { Gonzalez-Benito, } \\
\text { J }\end{array}$ & $\begin{array}{l}\text { International } \\
\text { Journal of } \\
\text { Production } \\
\text { research }\end{array}$ & 2019 & $\begin{array}{c}\text { Secondary } \\
\text { data }\end{array}$ & $\begin{array}{l}\text { Several } \\
\text { European } \\
\text { countries }\end{array}$ & Several & & $x$ & \\
\hline $\begin{array}{l}\text { Martínez-Mora, } \\
\text { C., Merino, F }\end{array}$ & $\begin{array}{l}\text { Journal of } \\
\text { Purchasing and } \\
\text { Supply } \\
\text { Management }\end{array}$ & 2014 & $\begin{array}{l}\text { Semi- } \\
\text { structured } \\
\text { interview }\end{array}$ & Spain & Footwear & $x$ & & \\
\hline $\begin{array}{l}\text { Moretto, A, } \\
\text { Patrucco, AS, } \\
\text { Harland, CM }\end{array}$ & $\begin{array}{l}\text { Internatuional } \\
\text { Journal of } \\
\text { Production } \\
\text { Economics }\end{array}$ & 2019 & Case studies & Italy & Several & $x$ & & $x$ \\
\hline $\begin{array}{l}\text { Nujen, B.B., } \\
\text { Halse, L.L., } \\
\text { Damm, R., }\end{array}$ & $\begin{array}{l}\text { Journal of } \\
\text { Manufacturing } \\
\text { Technology } \\
\text { Management }\end{array}$ & 2018 & Case studies & $\begin{array}{l}\text { Scandinavian } \\
\text { countries }\end{array}$ & Several & $x$ & $x$ & \\
\hline
\end{tabular}


Gammelsæter,

\begin{tabular}{|c|c|c|c|c|c|c|c|c|c|}
\hline $\begin{array}{l}\text { Nujen, B.B., } \\
\text { Mwesiumo, D.E., } \\
\text { Solli-Sæther, H., } \\
\text { Slyngstad, A.B., } \\
\text { Halse, L.L. }\end{array}$ & $\begin{array}{l}\text { Journal of Global } \\
\text { Operations and } \\
\text { Strategic Sourcing }\end{array}$ & 2019 & Case studies & Norway & Several & & $x$ & & \\
\hline $\begin{array}{l}\text { Pal, Harper, } \\
\text { Vellesalu }\end{array}$ & $\begin{array}{l}\text { The International } \\
\text { Journal of Logistic } \\
\text { Management }\end{array}$ & 2018 & Delphi study & Sweden & Clothing & & $x$ & $x$ & \\
\hline Srai, J.S., Ané, C. & $\begin{array}{l}\text { International } \\
\text { Journal of } \\
\text { Production } \\
\text { Research }\end{array}$ & 2016 & Survey & France \& UK & Several & $x$ & & & \\
\hline $\begin{array}{l}\text { Stentoft, J., } \\
\text { Mikkelsen, O.S., } \\
\text { Jensen, J.K. }\end{array}$ & $\begin{array}{l}\text { Operations } \\
\text { Management } \\
\text { Research }\end{array}$ & 2016 & $\begin{array}{c}\text { Mixed } \\
\text { (Survey }+2 \\
\text { case studies) }\end{array}$ & Denmark & Several & $x$ & & & \\
\hline $\begin{array}{l}\text { Stentoft, J., } \\
\text { Mikkelsen, O.S., } \\
\text { Jensen, J.K. }\end{array}$ & $\begin{array}{l}\text { Supply Chain } \\
\text { Forum }\end{array}$ & 2016 & Survey & Denmark & Several & $x$ & $x$ & $x$ & $x$ \\
\hline $\begin{array}{l}\text { Stentoft, } \\
\text { J., Mikkelsen, } \\
\text { O.S., Jensen, } \\
\text { J.K., Rajkumar, } \\
\text { C. }\end{array}$ & $\begin{array}{l}\text { International } \\
\text { Journal of } \\
\text { Production } \\
\text { Economics }\end{array}$ & 2018 & Survey & Denmark & Several & & & & $x$ \\
\hline
\end{tabular}




\section{Appendix 2:}

\section{Interview questions}

Conceptual Questions:

1. What's your role and responsibility in the company?

2. Can you explain the structure of the company?

3. What production does the company manufacture? Which market do you supply?

Phase1: Manufacturing at home

Which product was produced locally? Which market does it supply?

1. What's the outcome of producing locally?

2. What benefits you gained from producing locally?

3. What risks did you encountered during this phase?

Phase2: Manufacturing offshore

Which product was offshored? Which market does it supply?

1. Why did your company decide to offshore manufacturing? What was the motivation?

2. What benefits and risks did you expect to have before the implementation of this offshoring strategy?

3. What was the outcome of offshoring manufacturing?

4. What benefits did you experience while manufacturing was offshored?

5. What risks have you encountered while manufacturing was offshored?

6. How the outcome of offshoring compared with that expectation?

Phase3: Back-shoring manufacturing to the UK

Which product was Back-shored? Which market does it supply?

1. Why did your company decide to Back-shoring manufacturing? What was the motivation?

2. What benefits and risks did you expect to have before the implementation of this Backshoring strategy?

3. What was the outcome of Back-shoring manufacturing?

4. What benefits did you experience while manufacturing was Back-shored?

5. What risks have you encountered while manufacturing was Back-shored?

6. How the outcome of Back-shoring compare with that expectation?

7. What's your future offshoring or Back-shoring plan? 


\title{
Post-Brexit back-shoring strategies:
}

\section{what UK manufacturing companies could learn from the past?}

\author{
Moradlou, Hamid
}

Taylor and Francis

Moradlou H, Fratocchi L, Skipworth H, Ghadge A. (2021) Post-Brexit back-shoring strategies:

what UK manufacturing companies could learn from the past? Production Planning and Control, Volume 33, Issue 14, 2022, pp. 1319-1336

https://doi.org/10.1080/09537287.2020.1863500

Downloaded from Cranfield Library Services E-Repository 